\title{
Molybdenum dynamics in sediments of a seasonally-hypoxic coastal marine basin
}

\section{Sulu-Gambari, Fatimah}

2017

Sulu-Gambari , F , Roepert , A , Jilbert , T S , Hagens , M , Meysman , F \& Slomp , C P 2017

, ' Molybdenum dynamics in sediments of a seasonally-hypoxic coastal marine basin ', Chemical Geology , vol. 466 , pp. 627-640 . https://doi.org/10.1016/j.chemgeo.2017.07.015

http://hdl.handle.net/10138/308975

https://doi.org/10.1016/j.chemgeo.2017.07.015

cc_by_nc_nd

acceptedVersion

Downloaded from Helda, University of Helsinki institutional repository.

This is an electronic reprint of the original article.

This reprint may differ from the original in pagination and typographic detail.

Please cite the original version. 
1 Molybdenum dynamics in sediments of a seasonally-hypoxic coastal marine basin

2 Fatimah Sulu-Gambari $^{1 *}$, Anne Roepert ${ }^{1}$, Tom Jilbert ${ }^{1,2}$, Mathilde Hagens ${ }^{1}$, Filip J. R.

$3 \quad$ Meysman $^{3}$ and Caroline P. Slomp ${ }^{1}$

4

$5{ }^{1}$ Department of Earth Sciences (Geochemistry), Faculty of Geosciences, Utrecht University, 6 P.O. Box 80.021, 3508 TA Utrecht, the Netherlands

$7{ }^{2}$ Department of Environmental Sciences, Faculty of Biological and Environmental Sciences, 8 University of Helsinki, Finland

$9 \quad{ }^{3}$ NIOZ Royal Netherlands Institute for Sea Research, Department of Estuarine and Delta 10 Systems, P.O. Box 140, 4400 AC Yerseke, the Netherlands, and Utrecht University.

*Corresponding author: tel: + 3130253 5037; e-mail: fatimah.sulu-gambari@uu.nl 


\section{Abstract}

Molybdenum (Mo) enrichments in marine sediments are a common indicator of the presence of sulphide near the sediment-water interface and can thereby record historic bottom-water oxygen depletion. Here, we assess the impact of temporal changes in manganese (Mn) cycling and bottom-water oxygen on sedimentary Mo dynamics in a seasonally-hypoxic coastal marine basin (Lake Grevelingen, the Netherlands). High resolution line scans obtained with LA-ICPMS and discrete sample analyses reveal distinct oscillations in Mo with depth in the sediment. These oscillations and high sediment Mo concentrations (up to $\sim 130 \mathrm{ppm}$ ) are attributed to deposition of Mo-bearing Mn-oxide-rich particles from the overlying water, the release of molybdate $\left(\mathrm{MoO}_{4}{ }^{2-}\right)$ to the pore water upon reduction of these Mn-oxides, and subsequent sequestration of Mo. The latter process only occurs in summer when sulphide concentrations near the sediment-water interface are elevated. We hypothesise that cable bacteria enhance the seasonality in sediment Mo records by contributing to remobilisation of $\mathrm{Mo}$ as $\mathrm{MoO}_{4}{ }^{2-}$ during oxic periods and by enhancing the pool of Mn-oxides in the system by dissolving Mncarbonates. A sediment record that spans the past $\sim 45$ years indicates that sediment Mo concentrations have increased over the past decades, despite less frequent occurrences of anoxia in the bottom waters based on oxygen measurements from water column monitoring. We suggest that the elevated Mo in recent sediments reflects both enhanced rates of sulphate reduction and sulphide production in the surface sediment as a result of increased input of organic matter into the basin from the adjacent North Sea since 1999, and an associated enhanced "Mn refluxing" in the marine lake in summer. 


\section{Introduction}

Molybdenum (Mo) is the most abundant trace metal in the modern ocean (105 nM (Collier, 1985)) but is only a minor constituent of the Earth's crust (1-2 ppm; (Turekian and Wedepohl, 1961)). This discrepancy reflects the fact that molybdate $\left(\mathrm{MoO}_{4}{ }^{2-}\right)$ behaves conservatively in oxic seawater, leading to an accumulation of Mo in the oceans and a residence time of $\sim 4.4 \times 10^{5}$ years (Miller et al., 2011). However, Mo can be removed from seawater to marine sediments in the presence of hydrogen sulphide $\left(\mathrm{H}_{2} \mathrm{~S}\right)$, making sedimentary Mo an important proxy for past redox conditions. Under sulphidic conditions, multiple thiomolybdate intermediates $\left(\mathrm{MoO}_{\mathrm{x}} \mathrm{S}_{4-}\right.$ $\left.\mathrm{x}^{2-}\right)($ Erickson and Helz, 2000; Helz et al., 1996) and complexes of Mo with organic ligands (Wagner et al., 2017) can form. However, when $\mathrm{H}_{2} \mathrm{~S}$ concentrations in seawater or pore water exceed $\sim 11 \mu \mathrm{M}$, complete conversion to tetrathiomolybdate $\left(\mathrm{MoS}_{4}{ }^{2-}\right)$ is thought to occur (Erickson and Helz, 2000; Helz et al., 1996; Wagner et al., 2017). Molybdenum can subsequently be sequestered through multiple co-occurring pathways involving organic matter, Fe phases and/or authigenic sulphides (Algeo and Tribovillard, 2009; Chappaz et al., 2014; Dahl et al., 2017; Freund et al., 2016; Tribovillard et al., 2006; Wagner et al., 2017). As long as the supply of Mo to the seawater in a given environment is not restricted (Algeo and Lyons, 2006), the redox-sensitive behaviour of Mo allows discrimination between two distinct bottomwater oxygen regimes. More specifically, depositional settings with oxic bottom waters in which sulphide is limited to pore waters throughout the year (sediment Mo $<25 \mathrm{ppm}$ ) can be separated from those characterised by permanent anoxic and sulphidic conditions (i.e. euxinia) in bottom waters (sediment Mo > 100 ppm (Scott and Lyons, 2012)).

Bottom-water hypoxia $\left(\mathrm{O}_{2}<62.5 \mu \mathrm{M}\right.$ (Levin et al., 2009; Rabalais et al., 2010)) has become increasingly prevalent in coastal environments worldwide over the past decades. This has led to so-called "dead zones", where the sediment and bottom-water are devoid of larger fauna (Diaz and Rosenberg, 2008; Rabalais et al., 2014). The increase in these dead zones is 
often directly linked to increased nutrient input from land, which fuels algal blooms, thus enhancing the oxygen demand in deeper waters when algal material sinks to the seafloor (Carstensen et al., 2014; Diaz and Rosenberg, 2008). Sediment Mo records can provide valuable information on the timing of the onset of human-induced hypoxia, anoxia or euxinia and its further development (Gooday et al., 2009; Helz and Adelson, 2013). In the deep basins of the Baltic Sea, for example, a strong enrichment of Mo is observed in the upper $\sim 20 \mathrm{~cm}$ of the sediment (up to $\sim 220 \mathrm{ppm}$ ), in accordance with the establishment of euxinic conditions in the bottom waters of these basins since $\sim 1980$ (Jilbert and Slomp, 2013b; Mort et al., 2010; Scholz et al., 2013). Similarly, the expansion of hypoxic bottom waters in Chesapeake Bay since 1960 has been linked to an increased burial of Mo in the sediment (Adelson et al., 2001b; Helz and Adelson, 2013; Olson et al., 2017).

In non-euxinic settings, there are two main sources of Mo to sediments. First, $\mathrm{MoO}_{4}{ }^{2-}$ may diffuse into sediments from the overlying water where it may be sequestered in $\mathrm{H}_{2} \mathrm{~S}$ bearing pore waters (e.g. (Emerson and Huested, 1991; Tribovillard et al., 2006; Zheng et al., 2000)). Second, manganese-oxide particles may act as a major carrier of Mo to the sediment (Adelson et al., 2001b; Algeo and Lyons, 2006; Scheiderich et al., 2010). The input of Mo associated with Mn oxides can lead to two vertically-separated sediment enrichments in Mo: (1) an enrichment associated with Mn oxides at or near the sediment-water interface that is only a transient sink for Mo, and (2) an enrichment of Mo associated with sulphur and/or organic matter at depth that acts as a permanent sink (Morford et al., 2007; Scott and Lyons, 2012). Such dual Mo enrichments can be a permanent feature in sediments with oxic bottom waters (Malcolm, 1985). The release of Mo from Mn-oxides near the sediment-water interface may support a flux of Mo from the sediment to the overlying water. Such an efflux of Mo will prevent diffusion of Mo into the sediment (e.g. (Scott and Lyons, 2012)). In seasonally-hypoxic settings, the remobilisation of dissolved Mn from sediments, formation of Mn oxides in the 
water column and re-deposition of Mo-bearing Mn-oxides on the sediment in summer may lead to such a high input of Mo that the diffusive loss of $\mathrm{MoO}_{4}{ }^{2-}$ becomes unimportant relative to its input and conversion to tetrathiomolybdate (e.g. (Adelson et al., 2001a)). This so-called "Mnrefluxing" is thought to contribute to the high Mo burial fluxes in environments with weakly sulphidic bottom waters (Algeo and Lyons, 2006). To our knowledge, there are no detailed seasonal studies of the dynamics of Mo and Mn in both pore waters and sediments of hypoxic systems to confirm the suggested seasonality in coupled Mn-Mo cycling.

Recently, it was discovered that sulphide-oxidising cable bacteria (Nielsen et al., 2010; Pfeffer et al., 2012) may dissolve Fe-sulphides and Mn-carbonates in surface sediments of seasonally-hypoxic systems. Consequently, these bacteria actively contribute to the formation of an oxidised, Fe- and Mn-oxide rich surface layer in winter and spring (Seitaj et al., 2015; Sulu-Gambari et al., 2016b; Sulu-Gambari et al., 2016a). In contrast, sulphur oxidising Beggiatoaceae, present in autumn, had a more limited effect on the formation of Fe- and Mnoxides in the surface sediment (Seitaj et al., 2015; Sulu-Gambari et al., 2016b; Sulu-Gambari et al., 2016a). Due to the coupling of Mn, Fe, S and Mo cycles in hypoxic systems, we hypothesise that the activity of cable bacteria may also be of relevance to the sedimentary dynamics of Mo. More specifically, we hypothesise that cable bacteria activity may amplify seasonal oscillations in sediment Mo linked to bottom-water hypoxia. This hypothesis is based on their role in the efficient re-dissolution of sulphide-associated Mo in winter and spring, and in enhancing the pool of Mn-oxides by dissolving Mn-carbonates (Rao et al., 2016; SuluGambari et al., 2016b).

Here, we investigate the evolution of sediment and pore-water Mo profiles over one year in a seasonally hypoxic marine basin (Lake Grevelingen, the Netherlands). We focus on identifying the relationship between seasonal and spatial differences in bottom-water oxygen and the dynamics of Mo and Mn in the sediment. We assess whether sulphide-oxidising cable 
bacteria and Beggiatoaceae, which are both known to be present in our study basin for at least part of the year (Seitaj et al., 2015; Sulu-Gambari et al., 2016b; Sulu-Gambari et al., 2016a) can impact the sequestration of Mo in the sediment. Our results reveal strong annual oscillations in sedimentary Mo content driven by seasonal hypoxia and amplified by Mn refluxing and the activity of sulphide-oxidising bacteria. Furthermore, using an extended sediment record for the past 45 years we show how the long-term evolution of sedimentary Mo content reflects changes in pore water sulphide concentrations and Mn refluxing.

\section{Methods}

\subsection{Study sites and sample collection}

Lake Grevelingen (Figure 1) is a former estuary of the rivers Rhine and Meuse. The lake was formed by the construction of a landward dam (1965) and seaward dam (1971) in response to flooding caused by a storm surge (1953). The shallow lake covers an area of $115 \mathrm{~km}^{2}$ and has an average depth of $5.1 \mathrm{~m}$ but is intersected by several channels, of which the deepest (main channel) has a maximum water depth of $48 \mathrm{~m}$ (Figure 1) (Hagens et al., 2015; Sulu-Gambari et al., 2016b). The salinity of the lake falls within a stable range of 29 to 32 that is maintained via an exchange with the saline water from the North Sea through an underwater sluice in the Brouwersdam (Paulij et al., 1990). In spring and summer a temperature-dependent stratification develops in the main channel (Hagens et al., 2015). Bottom-water hypoxia has developed in the main channel in summer since 1971 (Wetsteyn, 2011).

Three sites, located along a water-depth gradient (sites 1-3, with water depths of 34, 23 and $17 \mathrm{~m}$ respectively) in the Den Osse basin in the main channel of Lake Grevelingen $\left(51.747^{\circ} \mathrm{N}\right.$, $3.890^{\circ} \mathrm{E} ; 51.749^{\circ} \mathrm{N}, 3.897^{\circ} \mathrm{E} ; 51.747^{\circ} \mathrm{N}, 3.898^{\circ} \mathrm{E}$ ), were sampled monthly in 2012 on board 
$\mathrm{R} / \mathrm{V}$ Luctor (Figure 1). Sediment accumulation rates at sites 1, 2 and 3 were previously estimated at $\sim 2,0.8$ and $0.4 \mathrm{~cm} \mathrm{yr}^{-1}$, respectively (Malkin et al., 2014; Sulu-Gambari et al., 2016b; Sulu-Gambari et al., 2016a). Discrete water column samples were collected at 8 water depths $(1,3,6,10,15,25$ and $32 \mathrm{~m})$ using a 12 L Niskin bottle and gas-tight Tygon tubing. Oxygen concentrations were measured in the collected samples using an automated Winkler titration procedure (Hagens et al., 2015).

Bottom-water oxygen concentrations between 1978 and 2011 were available for site 1 through a monthly monitoring programme operated by the Ministry of Infrastructure and the Environment (RWS) (Wetsteyn, 2011). Oxygen concentrations were assigned to specific time intervals each year and assumed to start and end in the middle of the interval between consecutive sampling dates. Each time interval was classified as 'anoxic' $(<1 \mu \mathrm{M}$ oxygen), 'hypoxic' (1-62.5 $\mu \mathrm{M}$ oxygen), 'oxic' (> $62.5 \mu \mathrm{M}$ oxygen) or 'not determined', depending on the oxygen concentration and whether or not sampling was conducted.

Short sediment cores $(\sim 40 \mathrm{~cm})$ with $\sim 20 \mathrm{~cm}$ of overlying water were collected at the three sites with a gravity corer (UWITEC, Austria) using Plexiglas ${ }^{\circledR}$ core-liners ( $6 \mathrm{~cm}$ inner diameter; $60 \mathrm{~cm}$ length). In addition to monthly sampling, a long core capturing the upper $90 \mathrm{~cm}$ of the sediment was obtained with the UWITEC corer ( $6 \mathrm{~cm}$ inner diameter; $120 \mathrm{~cm}$ liner length) at site 1 in May 2012. With an average sediment accumulation rate of $\sim 2 \mathrm{~cm} \mathrm{yr}^{-1}$ and duration of the lake phase of $\sim 41$ years, since the closure of the system, the estuarine-lacustrine transition in this core is expected near a depth of $82 \mathrm{~cm}$.

\subsection{Sediment slicing, bottom-water and pore-water analyses}


The long core and the upper $10 \mathrm{~cm}$ of the sediment in each short core was sliced at a resolution of $0.5 \mathrm{~cm}$ in a $\mathrm{N}_{2}$-purged glove-bag. Pore-water samples were collected through centrifugation of the sediment from the short cores (15 minutes at $4500 \mathrm{~g}$ ). Pore-water data for major solutes, Fe, $\mathrm{Mn}$ (assumed to be $\mathrm{Fe}^{2+}$ and $\mathrm{Mn}^{2+}$, although some $\mathrm{Mn}^{3+}$ may also be present; (Madison et al., 2013)), $\mathrm{Ca}^{2+}$ and $\mathrm{SO}_{4}{ }^{2-}$ and nutrients for sites 1-3 are presented and discussed by (SuluGambari et al., 2016b; Sulu-Gambari et al., 2016a). Here, we focus mainly on the water column and pore water at site 1 and include new data on trace metals, including high-resolution depth profiles. For sites 2 and 3, only water column data and discrete solid phase data are shown. Bottom- and pore-water samples for site 1 for January, March, May, June, July, August, September and November 2012, were filtered $(0.45 \mu \mathrm{m})$ and sub-sampled under $\mathrm{N}_{2}$ for various analyses. Subsamples were acidified with concentrated suprapur $\mathrm{HCl}(37 \%, 10 \mu 1$ per ml), stored at $4^{\circ} \mathrm{C}$ and analysed for dissolved Fe, Mn and Ca by Inductively Coupled Plasma Optical Emission Spectrometry (ICP-OES; Perkin Elmer Optima 3000; detection limit $<0.01$ ppm) and for dissolved Mo, Ni and V by ICP Mass Spectrometry (ICP-MS; Thermo Scientific X-series; detection limit $<0.3 \mathrm{ppb})$. Subsamples for sulphide $(0.5 \mathrm{ml})$ were fixed with a $2 \%$ zinc-acetate solution $(2 \mathrm{ml})$ and stored at $4{ }^{\circ} \mathrm{C}$. Sulphide was measured spectrophotometrically (Cline, 1969). A separate pore water aliquot was analysed for sulphate using a Dionex Ion Chromatograph.

\subsection{Sediment Analyses}

Centrifuged sediment samples from the short cores were freeze-dried and ground in a $\mathrm{N}_{2}$-purged glove-box for analyses (January 2012 for sites 1 and 3 and March, May, August and November 2012 for all three sites). Selected data (sediment $\mathrm{C}_{\text {org }}, \mathrm{Mn}, \mathrm{S}$ ) for sites 1, 2 and 3 were presented previously by (Sulu-Gambari et al., 2016b; Sulu-Gambari et al., 2016a). Here, we use these data to provide context for our trace metal analyses. The samples from the long core taken at site 1 in May 2012 were treated in the same manner as the short cores. The porosity of the 
sediment was calculated from the weight loss upon freeze-drying assuming a sediment density of $2.6 \mathrm{~g} \mathrm{~cm}^{-3}$. Total organic carbon $\left(\mathrm{C}_{\text {org }}\right)$ was measured using an elemental analyser (Fison Instruments, model NA $1500 \mathrm{NCS}$ ), after removing carbonate from the sediment with $1 \mathrm{M} \mathrm{HCl}$. Total S, Fe, Mn, Mo, Al, Ni and V were determined by ICP-OES and verified by ICP-MS for those samples with measurements close to detection limits, following acid destruction of ground samples $(\sim 0.125 \mathrm{~g})$ in a closed Teflon bomb at $90{ }^{\circ} \mathrm{C}(12 \mathrm{hr})$ using a mixture of $2.5 \mathrm{ml} \mathrm{HF}$ (40\%) and $2.5 \mathrm{ml}$ of a $72 \% \mathrm{HClO}_{4} / 65 \% \mathrm{HNO}_{3}$ mixture (volumetric ratio 3:2), evaporation of the acids at $190{ }^{\circ} \mathrm{C}$ and dissolution of the resulting gel in $(25 \mathrm{ml}) 1 \mathrm{M} \mathrm{HNO}_{3}$ (respective detection limits for Mn, Mo, Fe, Al, Ni and V were 0.03, 0.3, 54.2, 0.08, 0.05 and $0.2 \mathrm{ppb}$ (ICP MS) and $0.28 \mathrm{ppm}$ for $\mathrm{S}$ (ICP OES)) in the $1 \mathrm{M} \mathrm{HNO}_{3}$ solution).

\subsection{Laser Ablation ICP-MS}

Sub-cores of sediment ( $1 \mathrm{~cm}$ diameter, $\sim 7 \mathrm{~cm}$ length) were taken from the surface sediment at site 1 in March and August 2012 as described by (Jilbert and Slomp, 2013a). The sediment in each sub-core was dehydrated with argon-purged acetone and fixed in Spurr's epoxy resin, and subsequently sliced into sections $(\sim 3.5 \mathrm{~cm})$ with a water-cooled rotating blade for highresolution elemental analysis and polished (Jilbert et al., 2008). Polished sections were analysed using Laser Ablation Inductively Coupled Plasma Mass Spectrometry (LA-ICP-MS) line scanning.

Elemental line scan profiles were generated by focussing a pulsed argon-fluoride excimer laser beam $\left(120 \mu \mathrm{m}\right.$ spot size, $193 \mathrm{~nm}$ wavelength, $10 \mathrm{~Hz}$ repetition rate, and $8 \mathrm{~J} \mathrm{~cm}^{-2}$ energy density) onto the moving sample surface and ablating material into a high mass resolution ICPMS (Thermo Element 2) in a continuously flowing helium-argon carrier gas. During line scans the stage velocity was set to $0.0275 \mathrm{~mm} \mathrm{~s}^{-1}$ for high spatial resolution measurements 
(Hennekam et al., 2015). Count rates of isotopes ${ }^{27} \mathrm{Al},{ }^{55} \mathrm{Mn}$ and ${ }^{98} \mathrm{Mo}$ were determined, among other isotopes, at a measurement frequency of approximately $1 \mathrm{~Hz}$.

Line scans of each polished section were connected to construct a single record. The resin embedding procedure results in varying degrees of sediment compaction, such that the length of each line scan is less than the original $\sim 7 \mathrm{~cm}$ sub-core. To correct for compaction effects, the data from each LA-ICP-MS line scan was linearly re-scaled to the initial length of the sub-core. Subsequently, line scan data were fine-tuned by alignment to ICP-OES dada of discrete samples from the corresponding interval. Raw LA-ICP-MS count data were converted to elemental compositional ratios as described in (Jilbert and Slomp, 2013a), with further modifications as described by (Roepert et al., 2016).

\subsection{Suspended matter}

Water samples for suspended matter filtration were collected by Niskin bottle at site 1 as described in section 2.1. During most months, water was transferred from the Niskin bottle to 2.5 L high-density polyethylene jerry cans, from which ca. $2500 \mathrm{ml}$ was subsequently filtered through pre-weighed, pre-combusted Whatman GF/F filters (nominal pore size $0.7 \mu \mathrm{m}$ ). In July and August, when bottom waters were experiencing severe hypoxia/ anoxia, water below $10 \mathrm{~m}$ depth was collected in volume-calibrated plastic bottles of $\sim 2 \mathrm{~L}$ and filtered in a closed system, to limit oxygen contamination. Filters were rinsed with UHQ water to remove sea salts and stored at $-20{ }^{\circ} \mathrm{C}$ until analysis.

The filters were freeze-dried and weighed, and suspended particulate matter concentrations $\left(\mathrm{mg} \mathrm{L}^{-1}\right)$ were calculated from the weight after freeze-drying and the total filtered volume of water. After acid digestion, as described in Section 2.3, Mn concentrations were measured in the $\mathrm{HNO}_{3}$ solutions by ICP-OES. The acid solutions from water depths of 25 and $32 \mathrm{~m}$ for 
April, May, June, July and August were additionally analysed for Mn and Mo by ICP-MS. The ICP-OES and -MS analyses for Mn always agreed within 5\%. The Mn measurements were corrected for filter blanks (always less than 5\% of $\mathrm{Mn}$ in suspended matter) and $\mathrm{Mn}$ concentrations were converted to ppm (mg per kg of solids). Given the high Mo blanks of the GF/F filters (5-75\% of the Mo in the suspended matter), the Mo analyses for the suspended matter are approximations only and, therefore, we present only the average value for all 5 months.

\subsection{Diffusive flux calculations}

Diffusive fluxes of Mo at the sediment-water interface $(\mathrm{J})$ were calculated from pore water profiles for site 1 using Fick's first law (Boudreau, 1997):

$$
\mathrm{J}=-\varphi \mathrm{D}_{\mathrm{s}} \frac{d C}{d x}
$$

where $\varphi$ is the porosity, $D_{s}$ is the diffusion coefficient in the sediment, and $\frac{d C}{d x}$ is the gradient in the dissolved Mo concentration between the bottom water and the first sediment depth interval (where the distance to the midpoint is $0.25 \mathrm{~cm}$ ). Diffusion coefficients in the sediment were calculated using the $\mathrm{R}$ marelac package (Soetaert et al., 2010), in which the 'difcoeff' function was modified to include Mo using the diffusion coefficient in seawater from (Li and Gregory, 1974). The 'difcoeff' function includes corrections for salinity, temperature and the tortuosity of the sediment (Boudreau, 1997). Downward fluxes of Mo into the dissolved sulphide-bearing zone were calculated in the same manner with the depth interval being determined by the depth at which dissolved sulphide was detected.

\section{Results}




\subsection{Water column}

Bottom-water oxygen concentrations displayed a clear seasonal cycle at all three sites in 2012 (Figure 2A). While oxygen concentrations were high $\left(\mathrm{O}_{2}>200 \mu \mathrm{M}\right)$ in winter and autumn, they decreased in spring and summer (from May to August) at all three sites. Distinct differences were observed between sites 1 and 2 where the bottom water became hypoxic $\left(\mathrm{O}_{2}<62.5 \mu \mathrm{M}\right)$ in summer, compared to site 3 where oxygen concentrations always remained above the threshold for hypoxia. Anoxia $\left(\mathrm{O}_{2}<1 \mu \mathrm{M}\right)$ and the presence of sulphide in the bottom water $(\sim 3 \mu \mathrm{M})$ was only observed at site 1 in August.

Long-term monitoring data show that bottom-water anoxia was a regular feature in the basin in summer between 1979 and 1997 (Figure 2B). In contrast, between 1998 and 2010, the bottom water was mostly hypoxic in summer. During the latter 12 year period, there was no clear trend in the duration of hypoxia. While a relatively long period of anoxia occurred in 2011 (Figure 2B), the duration of hypoxia was again comparably short in 2012 (Figure 2A).

Suspended matter concentrations at site 1 were highest in January and in late summer and autumn (Figure S1). Depth-integrated amounts of suspended matter in the water column ranged from $\sim 65$ to $230 \mathrm{~g} \mathrm{~m}^{-2}$ (Table S1). Concentrations of $\mathrm{Mn}$ in the suspended matter showed a strong seasonal variation, with highest concentrations near the lake bottom $(>40,000 \mathrm{ppm})$ in July and August (Figure 3). Weight ratios of Mo/Mn in the suspended matter, from water depths of 25 and $32 \mathrm{~m}$ (between April and August), average $0.0030 \pm 0.0026$.

\subsection{Pore-water chemistry}

High concentrations of $\mathrm{Fe}^{2+}$ and $\mathrm{Mn}^{2+}$ were observed in the upper $4 \mathrm{~cm}$ of the sediment at site 1 in January and March 2012 (Figure 4). Dissolved $\mathrm{Fe}^{2+}$ was low in June and then absent from the pore water from July onward, while $\mathrm{Mn}^{2+}$ concentrations were low during the rest of the 
year. Sulphide was present in the pore water below 4 to $5 \mathrm{~cm}$ depth from January to May, but closer to the sediment surface in June and July (2 and $0.5 \mathrm{~cm}$ depth, respectively). In August, in contrast, sulphide was present in the bottom water $(\sim 3 \mu \mathrm{M})$. In November, a sulphide-free zone developed again but now in the upper $2 \mathrm{~cm}$ of the sediment. The shapes of the pore water profiles of $\mathrm{Ca}^{2+}$ and $\mathrm{SO}_{4}{ }^{2-}$ are indicative of production of both solutes in the upper 4-6 $\mathrm{cm}$ of the sediment in January and March. For $\mathrm{Ca}^{2+}$, profiles were nearly constant with depth from May onward. A decrease in pore water $\mathrm{SO}_{4}{ }^{2-}$ with depth was observed in May, August and November.

Strong seasonal changes were observed in pore water Mo. In January and March, two subsurface maxima in pore water Mo were observed in the upper 4 to $6 \mathrm{~cm}$ of the sediment, with concentrations reaching $\sim 300 \mathrm{nM}$. In May, June and July only one sharp maximum in Mo near the sediment-water interface was found, with concentrations reaching up to $\sim 500 \mathrm{nM}$. In August, pore water Mo concentrations were very low and there was only a small enrichment near the sediment-water interface. In November, a slightly more distinct subsurface maximum in pore-water Mo $(\sim 130 \mathrm{nM})$ was present. Calculated diffusive fluxes of Mo across the sediment-water interface suggest release of Mo from the sediment during a major part of the year (Table 1). While the flux is near zero in March, an influx of Mo of 0.13 and $0.04 \mathrm{mg} \mathrm{m}^{-2}$ $\mathrm{d}^{-1}\left(1.4\right.$ and $\left.0.4 \mu \mathrm{mol} \mathrm{m} \mathrm{m}^{-2} \mathrm{~d}^{-1}\right)$ is calculated for July and August, respectively. Downward diffusive fluxes of Mo into the sulphide-bearing zone ranged from 0.04 to $0.15 \mathrm{mg} \mathrm{m}^{-2} \mathrm{~d}^{-1}(0.4$ to $1.6 \mu \mathrm{mol} \mathrm{m} \mathrm{m}^{-2} \mathrm{~d}^{-1}$.

Both $\mathrm{Ni}$ and $\mathrm{V}$ were present in the pore water throughout the upper $10 \mathrm{~cm}$ of the sediment. Pore-water Ni was elevated in the upper $\sim 4 \mathrm{~cm}$ of the sediment in January and March, but there were no other distinct trends with depth.

\subsection{Bulk sediment chemistry}


The sediments at all sites were rich in $\mathrm{C}_{\text {org }}$, with concentrations ranging from 0.5 to $7 \mathrm{wt} \%$ (Figures 5-7). At sites 1 and 2, concentrations of $\mathrm{C}_{\text {org }}$ oscillated with depth in the sediment, with site 1 having fewer maxima than site 2 . Such variations with depth were not observed at site 3 . While concentrations of Fe remained relatively constant with depth, there was a strong seasonality in the concentrations of S and $\mathrm{Mn}$ in the surface sediment at all three sites. In spring, the surface sediments at all sites were depleted in $\mathrm{S}$ and enriched in Mn relative to sediments at depth. In August and November, the surface sediments at all sites were enriched in S while Mn concentrations showed no change with depth. At site 1, distinct oscillations in concentrations of S with depth were observed.

Concentrations of Mo in the surface sediment at sites 1 and 2 showed a distinct seasonality, with low concentrations in January, March and May, high concentrations in August (up to 99 and $37 \mathrm{ppm}$, respectively) and either lower (site 1) or equally high concentrations (site 2) in November. The depth profiles at both sites showed distinct enrichments in Mo that coincide with maxima in the depth profiles of $\mathrm{C}_{\text {org }}$ and $\mathrm{S}$. At site 3 , Mo concentrations were very low $(<$ $15 \mathrm{ppm}$ ) and showed little change with depth. There was a high background of $\mathrm{Ni} / \mathrm{Al}$ and $\mathrm{V} / \mathrm{Al}$ in the sediment that was of a similar magnitude at all sites. Superimposed on this background, distinct oscillations with depth were observed at sites 1 and 2 with maxima that coincide with those of $\mathrm{C}_{\mathrm{org}}, \mathrm{S}$ and Mo.

\subsection{High-resolution solid-phase analyses}

LA-ICP-MS line scan profiles of Mn/Al and Mo/Al for March and August at site 1 confirm the major seasonal changes in Mn and Mo in the surface sediment and the oscillations with depth observed in the discrete sample data (Figure 8). Ratios of Mo/Mn (counts/counts) in the upper 
$\mathrm{mm}$ of the sediment determined with LA-ICP-MS were 0.002 and 0.015, in March and August, respectively.

\subsection{Long-term record of hypoxia}

A distinct change in sediment geochemistry was observed at $\sim 80 \mathrm{~cm}$ in the long core taken at site 1 in March 2012. This depth coincides with the depth of the expected estuarine-lacustrine transition based on the rate of sediment accumulation and suggests that at least the past 40 years of deposition in the lake are captured in this core. A distinct enrichment in $\mathrm{C}_{\text {org }}$ was observed in the surface layer of the long core taken in May 2012 at site 1 (Figure 9). The $\mathrm{C}_{\text {org }}$ content subsequently declined with depth to an oscillating background concentration of between 4 and $6 \mathrm{wt} \%$. Distinct oscillations with depth were also observed in the profiles of total Fe, S and Mo but not in the profile of Mn. Background and peak Mo concentrations decreased with increasing depth, with the most pronounced maxima being observed in the upper $40 \mathrm{~cm}$ of the sediment.

\section{Discussion}

\subsection{Impact of seasonal hypoxia on Mn dynamics}

Low oxygen conditions in bottom waters in summer are a recurring phenomenon in Lake Grevelingen since the formation of the lake in 1971 (Figure 2; (Wetsteyn, 2011)). The hypoxia and anoxia are directly related to the combination of a stratified water column in summer and a high oxygen demand in the deeper waters and sediment. This oxygen consumption is fuelled by local production, re-deposition of organic-rich sediment from shallower areas and the input of organic matter from the North Sea through sluices in the seaward dam of the lake (Hagens et al., 2015; Seitaj et al., 2016). 

the biogeochemistry of the lake sediments (Seitaj et al., 2015; Sulu-Gambari et al., 2016b; SuluGambari et al., 2016a). Summer hypoxia has previously been shown to lead to the dissolution

356 of Mn oxides in the surface sediments at all three sites (Figures 5-7; (Sulu-Gambari et al., 2016b)) and a loss of Mn from the sediment to the water column. While calculated diffusive fluxes suggest a loss of $\mathrm{Mn}^{2+}$ from the sediment to the overlying water throughout the year (with average Mn fluxes of $\sim 80 \mathrm{mg} \mathrm{m}^{-2} \mathrm{~d}^{-1}$ at site $1\left(\sim 1.45 \mathrm{mmol} \mathrm{m}^{-2} \mathrm{~d}^{-1}\right.$ (Sulu-Gambari et al., 2016b)), our suspended matter Mn data demonstrate that this release only leads to a strong seasonal enrichment of $\mathrm{Mn}$ in suspended matter in the lake in summer (Figure 3). The integrated amount of $\mathrm{Mn}$ in the water column in August at site $1\left(\sim 1200 \mathrm{mg} \mathrm{m}^{-2}\right.$; Figure 3, Table $\left.\mathrm{S} 1\right)$ is more than a factor two lower than the amount released from the sediment, based on the seasonal change in the surface enrichment in $\mathrm{Mn}\left(\sim 2800 \mathrm{mg} \mathrm{m}^{-2}\right.$; assuming a sediment density of $2.6 \times 10^{6} \mathrm{~g} \mathrm{~m}^{-3}$ and measured porosity of 0.93 ; Figure 5 ). This suggests that some of the Mn in the water column may be transported laterally out of the basin and/or may be re-deposited at shallower water depths.

Due to the presence of oxygen in most of the water column (Figure 2 (Hagens et al., 2015)), the particulate $\mathrm{Mn}$ in the suspended matter is assumed to be present as Mn oxides, formed by oxidation of $\mathrm{Mn}^{2+}$ diffusing from the sediments into the water column. Refluxing of Mn likely occurs throughout the summer, with gravity-driven settling of Mn-oxides fuelling further reductive dissolution in the surface sediments as described for Chesapeake Bay (Adelson et al., 2001a). We note one major difference with the Mn-refluxing observed in the latter system, however, which relates to the location of $\mathrm{Mn}^{2+}$ oxidation. In Chesapeake Bay, the $\mathrm{Mn}^{2+}$ is oxidised to Mn oxides just above the pycnocline in the water column and re-dissolved $\mathrm{Mn}^{2+}$ has to diffuse back through the pycnocline to complete the reflux cycle (Adelson et al., 2001a). In Lake Grevelingen, the pycnocline is located at a water depth of $\sim 10 \mathrm{~m}$ in July and August 
(Hagens et al., 2015) and most Mn oxides are formed well below the pycnocline (Figure 3).

Because of the shorter diffusion pathway of $\mathrm{Mn}^{2+}$ before it meets oxygen, Mn cycling in the water column in Lake Grevelingen is likely more rapid than in Chesapeake Bay. We also note that suspended matter concentrations of $\mathrm{Mn}$ in Lake Grevelingen remain relatively high in autumn when compared to spring (Figure 3), while surface concentrations of sediment Mn show the opposite pattern (Figures 5-7). This suggests that Mn refluxing continues in autumn, although to a lesser extent than in summer.

\subsection{Impact of seasonal hypoxia on Mo dynamics}

The strong seasonality in Mn dynamics has major consequences for the dynamics of Mo in the lake sediments, because of the close association of Mo with Mn-oxides. We will illustrate this using the data for site 1 . In late winter and spring, when the bottom water is oxygenated, surface sediments are enriched in Mn-oxides (Figure 5). The associated Mo enrichment is minor but detectable in the LA-ICP-MS line scan data (Figure 8). Pore water data for the same time of year show that Mn oxides are being dissolved at around 1-2 $\mathrm{cm}$ depth, releasing both $\mathrm{Mn}^{2+}$ and Mo, most likely mostly in the form of $\mathrm{MoO}_{4}{ }^{2-}$ (Figure 4). Some of this Mo may escape to the overlying water through diffusion, especially in January, for which we calculate a diffusive flux out of the sediment of $\sim 0.2 \mathrm{mg} \mathrm{m}^{-2} \mathrm{~d}^{-1}\left(1.9 \mu \mathrm{mol} \mathrm{m} \mathrm{m}^{-2} \mathrm{~d}^{-1}\right.$ (Table 1$)$. Given that there are only a few ppm of Mo in the surface sediment in spring (Figure 5 and 8) and 2 ppm sediment Mo over a depth of $1 \mathrm{~cm}$ would amount to ca. $3.6 \mathrm{mg} \mathrm{m}^{-2}$ (or $37 \mu \mathrm{mol} \mathrm{m} \mathrm{m}^{-2}$; assuming a sediment density of $2.6 \times 10^{6} \mathrm{~g} \mathrm{~m}^{-3}$ and using the measured porosity of 0.93 ), this implies that the diffusive flux of Mo either is sustained only for several weeks or that there is a continuous recycling of both Mn and Mo through the water column near the sediment-water interface. 
Upon the initial decline in oxygen in the bottom water in early summer (May and June),

402

403

404

405

406

407

408

409

410

411

412

413

414

415

416

417

Mn oxide concentrations decline in the surface sediment (Figure 5) and increase in the suspended matter (Figure 3). However, a small sub-surface peak in pore water Mn (June) indicates that the ongoing input of Mn oxides to the sediments is followed by rapid dissolution (Figure 4). At this time, the release of Mo into the pore waters, and hence the efflux across the sediment-water interface, is at its highest value at any time of the year $\left(0.6\right.$ and $1.4 \mathrm{mg} \mathrm{m}^{-2} \mathrm{~d}^{-}$ ${ }^{1}$ or 6.2 and $1.5 \mu \mathrm{mol} \mathrm{m}^{-2} \mathrm{~d}^{-1}$ for May and June, respectively). Release of Mo from Fe-oxides may provide an additional source of Mo at this time of year (e.g. (Algeo and Lyons, 2006; Goldberg et al., 2012)). Coincident subsurface peaks of $\mathrm{Fe}^{2+}$ and $\mathrm{Mn}^{2+}$ in June support this suggestion (Figure 4).

When bottom waters are hypoxic and anoxic in July and August (Figure 1), pore water concentrations of Mo are low (Figure 4) and diffusive fluxes of Mo are directed into the sediments (Table 1). The sulphide concentration in the upper $0.5 \mathrm{~cm}$ of the sediment is $\sim 725 \mu \mathrm{M}$. At a pH of $\sim 7.4$ (Sulu-Gambari et al., 2016b), this corresponds to a $\mathrm{H}_{2} \mathrm{~S}$ concentration of $\sim 100 \mu \mathrm{M}$ (Millero et al., 1988), which is greater than the concentration of $11 \mu \mathrm{M}$ required for quantitative conversion of molybdate to tetrathiomolybdate and sequestration of Mo into the solid phase (Adelson et al., 2001b; Helz et al., 1996). The sediment Mo profile for August indeed shows a distinct enrichment of Mo in the upper $\mathrm{cm}$ of the sediment that reaches a maximum value of $\sim 100 \mathrm{ppm}$. If the diffusive influx of July is assumed to be representative of the maximum influx for these two months and we assume an influx with a duration of 60 days, a total enrichment of Mo of only $\sim 15 \mathrm{ppm}$ in the upper $\mathrm{cm}$ can be achieved (assuming a sediment density of $2.6 \times 10^{6} \mathrm{~g} \mathrm{~m}^{-3}$ and the measured porosity of 0.98$)$. This indicates that the diffusive influx of $\mathrm{MoO}_{4}{ }^{2-}$ can only explain at most ca. $15 \%$ of the enrichment of Mo in the surface sediment at our site 1 in summer. We suggest that the remaining $85 \%$ of the Mo is supplied through input of Mn oxides from the overlying water. 
427 August (Figure 3). If we assume that this material has the same composition as the material arriving at the sediment-water interface, it is possible to estimate whether Mn oxide input could explain the observed surface-sediment enrichment in Mo at this time. With LA-ICP-MS, we determined an $\mathrm{Mo} / \mathrm{Mn}$ count ratio in oxic surface sediments of 0.002 , which is similar to the weight ratio calculated for sediments from a range of other sites (Shimmield and Price, 1986). Our average $\mathrm{Mo} / \mathrm{Mn}$ weight ratio in suspended matter was slightly higher at 0.003 . Assuming a Mn concentration in suspended matter of $\sim 40,000 \mathrm{ppm}$ and a Mo/Mn weight ratio of either 0.002 or 0.003 ), we calculate a Mo concentration of 80 or $120 \mathrm{ppm}$ in suspended matter. This suggests that indeed sufficient Mo can reach the sediment through Mn oxide deposition to account for most of the Mo enrichment. Critical to this interpretation is that Mo is sequestered after dissolution from Mn oxides, despite the loss of Mn itself from the sediments (Scholz et al., 2013).

Upon re-oxygenation of the water column in autumn, the surface layer of the sediments again contains some oxygen (Seitaj et al., 2016; Sulu-Gambari et al., 2016b). In November at site 1, a smaller Mo peak is present near the surface than in August (Figure 5). While this could be due to spatial variability in Mo accumulation, the smaller Mo peak could also indicate loss of Mo due to post-depositional oxidation (Crusius et al., 1996), which may mobilise organic and/or sulphide associated Mo. Hence, it is possible that the peaks in Mo deeper in the sediments (3-4 peaks observed in the top $10 \mathrm{~cm}$ at site 1 , Figure 5) represent past intervals in which Mo has accumulated, then partially remobilised, leaving a remnant peak of lower concentration.

\subsection{Seasonal hypoxia and sedimentary Mo sequestration}


The series of maxima in sedimentary Mo observed with depth at site 1 likely reflect seasonal cycles of Mo sequestration, given the sediment accumulation rate of $2 \mathrm{~cm} \mathrm{yr}^{-1}$. Note that in some cases Mo peaks may not represent the actual maxima upon deposition because of postdepositional oxidation. That maxima in Mo are related to seasonal hypoxia is supported by three additional lines of evidence. First, we observe similar Mo peaks at site 2, with the number of peaks in the upper $10 \mathrm{~cm}$ of the sediment being a factor two higher, which is in accordance with a sediment accumulation rate that is roughly half of that at site $1\left(0.8 \mathrm{~cm} \mathrm{yr}^{-1}\right.$ versus $2 \mathrm{~cm} \mathrm{yr}^{-1}$, Figure 6). Second, we observe that both $\mathrm{Ni} / \mathrm{Al}$ and $\mathrm{V} / \mathrm{Al}$ show similar profiles to Mo at sites 1 and 2 (Figures 5 and 6). Since these trace metals are also known to be redox-sensitive (Tribovillard et al., 2006), this supports the theory that seasonal changes in redox conditions drive variability in Mo/Al. Third, such seasonal maxima in Mo have been reported previously for another deep site in the lake (Egger et al., 2016). At this other site, the sediment accumulation rate is exceptionally high $\left(13 \mathrm{~cm} \mathrm{yr}^{-1}\right)$ thereby likely excluding post-depositional oxidation, and the magnitude of the Mo maximum has been shown to be directly correlated to the area of hypoxia in the lake (Egger et al., 2016).

The importance of the Mn-oxide mechanism in controlling Mo sequestration in the lake sediments is further illustrated by the distinct gradient in Mo concentrations in the sediment at the three sites (Figure 10; up to $130 \mathrm{ppm}$ at site 1 compared to 45 and $15 \mathrm{ppm}$ at sites 2 and 3, respectively). These sites are located along a gradient of increasing water depth and decreasing bottom-water oxygen (Figure 2), and, likely, increasing Mn oxide deposition (Figure 3). While there is a slight gradient in bottom water sulphide ( $3 \mu \mathrm{M}$ at site 1 ; none at sites 2 and 3$)$ in August 2012, consistent with the gradient in water depth, the sulphide concentrations in the upper $0.5 \mathrm{~cm}$ of the sediment pore water show a different trend. High sulphide concentrations are found in this sediment layer at all sites in August (725 $\mu \mathrm{M}$ (Figure 4), 1900 and $\sim 220 \mu \mathrm{M}$ (Sulu-Gambari et al., 2016b) for sites 1, 2 and 3, respectively). At the prevailing $\mathrm{pH}$ values of 
the pore water at these sites ( 7.4-7.5), corresponding concentrations of $\mathrm{H}_{2} \mathrm{~S}$ are always greater than $11 \mu \mathrm{M}$ (Helz et al., 1996; Millero et al., 1988). Hence, the potential for Mo sequestration based on the $\mathrm{H}_{2} \mathrm{~S}$ concentration (Helz et al., 1996) is expected to be similar at all sites in August, and it is likely that contrasting Mo accumulation largely reflects variable supply of Mo by Mn oxides. Surface-sediment Mn concentrations generally increase with increasing water column depth (in the order site $1>$ site $2>$ site 3 ) due to the gravitational focussing of Mn oxides into the deeper part of the basin during Mn refluxing (Figures 5 - 7). Hence, the higher supply of Mo via Mn oxides at the deepest site determines the high concentrations in the sediments in August.

The Mo concentrations at our site 1 are rather exceptional when compared to other seasonally hypoxic marine environments. In fact, in the classification of Scott and Lyons (2012), our summer values of up to 100 to $130 \mathrm{ppm}$ at site 1 would fall within the range for sediments with permanently euxinic bottom waters (> $100 \mathrm{ppm})$. We suspect that the strong $\mathrm{Mn}$ refluxing at our site explains this unusual seasonal enrichment in Mo (also see discussion in (Algeo and Lyons, 2006)). Figure 11 summarises our current understanding of the seasonal dynamics of Mo fixation in the sediment at site 1, demonstrating the need for both a high input of $\mathrm{Mn}$ oxides and high pore-water sulphide concentrations to allow for formation of Mo enrichments, and the corresponding temporal evolution in the sediment Mo profiles.

\subsection{Impact of sulphide-oxidising bacteria on Mo dynamics}

As discussed in detail by Sulu-Gambari et al. (2016a) and Seitaj et al. (2015), various lines of evidence including near-surface enrichments in pore water $\mathrm{Ca}^{2+}$ and $\mathrm{SO}_{4}^{2-}$ (Figure 4), microprofiles of oxygen, sulphide and $\mathrm{pH}$ profiles characteristic for cable bacteria and microscopic identification, point towards the presence of active cable bacteria at all three sites 
in the spring of 2012. The enrichments in pore water $\mathrm{Ca}^{2+}$ and $\mathrm{SO}_{4}{ }^{2-}$ are directly related to the proton production associated with the electrogenic metabolism of the cable bacteria and have been shown to be produced through dissolution of calcium carbonate and FeS at our field site (Sulu-Gambari et al., 2016a), supporting results of earlier laboratory experiments (RisgaardPetersen et al., 2012). At site 1, cable bacteria have also been shown to contribute to dissolution of Mn carbonates in the sediment (Sulu-Gambari et al., 2016b). Because part of the $\mathrm{Mn}^{2+}$ is oxidised in the surface sediment, this enhances the pool of Mn oxides in the lake system available for Mn refluxing.

In sediment with active cable bacteria, Mo associated with FeS would be expected to be released to the pore water concurrently with the dissolution of FeS. At site 1, we indeed find a distinct second maximum of pore water Mo in January and March (Figure 4) that could be explained by such a dissolution process. The depth of the pore water Mo maximum coincides with the maximum in pore water $\mathrm{Ca}^{2+}$, which is located at a greater depth than the maximum in $\mathrm{Fe}^{2+}$. This difference could be related to a faster removal of downward diffusing $\mathrm{Fe}^{2+}$ with pore water sulphide when compared to sulphide-driven fixation of Mo in the sediment. The ultimate fate of the Mo is thus sequestration, but at a greater depth than before. We can only speculate about the fate of the upward diffusing pore water Mo. One possibility is that it is bound to Feoxides that are known to be present below the Mn-oxide-bearing layer (Sulu-Gambari et al., 2016b; Sulu-Gambari et al., 2016a) and that their reduction contributes to the enhanced release of Mo to the pore water in May and June.

In summary, our data suggest that, through their active oxidation of the sediment in spring, cable bacteria could contribute to mobilisation of Mo deposited during the most recent prior period of hypoxia, with the Mo either escaping out of the sediment or being sequestered again at greater depth. The presence of cable bacteria could thus amplify the seasonal changes in sediment Mo. Whether these processes have a significant impact on sediment Mo records is 
difficult to deduce from the current data set and will depend on various factors, such as the rate of sediment accumulation at a given site, the depth to which FeS is removed and the initial amount of Mo associated with FeS. The downward fluxes of Mo (Table 1) when sustained over one month or more are sufficient to lead to measurable changes in Mo ( $\sim 10 \mathrm{ppm})$. Given that at our sites 1 and 2, distinct oscillations in sediment Mo are visible, these processes clearly do not lead to removal of the Mo enrichments. However, they could lead to changes in peak height or smearing of Mo profiles. We also note that, prior to the establishment of the cable bacteria, Beggiatoaceae were active at all 3 sites in autumn and contributed to oxidation of the surface sediment. Although this oxidation did not extend as deep as in the presence of the cable bacteria, and some of the changes seen from month to month may be related to spatial variability (as suggested by the data for site 2; Figure 6), the activity of Beggiatoaceae may have contributed to mobilisation of Mo in the near surface sediment as well.

\subsection{History of hypoxia}

Lake Grevelingen has a history of several decades of seasonal hypoxia (Figure 2) which is reflected in oscillating concentrations of $\mathrm{Mo}, \mathrm{S}$ and $\mathrm{Fe}$ in the sediment record for the past 40 years (Figure 10). To alleviate the hypoxia, the inflow of North Sea water at the seaward sluice was increased in 1999 (Wetsteyn, 2011). The increased inflow of this more saline, more oxygenated and warmer water indeed improved the oxygenation of the bottom waters in our study basin, mostly by reducing the temperature stratification in summer (Wetsteyn, 2011). As a consequence, anoxia in bottom waters generally became less frequent (Figure 2; (Wetsteyn, 2011)). Strikingly, however, the sediment Mo records suggest progressively sulphidic conditions in the pore waters towards the present day (Figure 9). We can reconcile these contrasting findings if we take into account that the inflowing North Sea water also carried large amounts of algal material (dominantly Phaeocystis globosa) into the lake in spring (Hagens et 
al., 2015; Seitaj et al., 2016; Wetsteyn, 2011). The degradation of this organic matter likely enhanced rates of sulphate reduction in late spring and summer, thereby increasing sulphide concentrations in the pore water and enhancing the rate of Mn refluxing. Combined, these factors could explain the increasing trend in sequestration of Mo at site 1 . This sequence of events is supported by the observation that the three major maxima in sediment Mo in the upper $32 \mathrm{~cm}$ of the long core coincide with maxima in organic carbon, with the maxima at ca. $32 \mathrm{~cm}$ depth likely reflecting the input of organic matter in 1999. In summary, our sediment Mo record reflects an increased input of organic matter and thus an increased oxygen demand of the sediment. This demand is outpaced by an increased oxygen supply linked to the reduced temperature stratification; bottom water anoxia in the basin has become less frequent.

\section{Conclusions}

Oscillations in molybdenum (Mo) in sediments in a seasonally-hypoxic marine basin (Lake Grevelingen) reflect seasonal variations in the presence of sulphide near the sediment-water interface and input of Mo with Mn-oxides. These results confirm the validity of Mo as a redox proxy. Manganese recycling in the surface sediments and water column ("Mn refluxing") is shown to play a key role as a carrier of the Mo to the sediment and explains the exceptionally high Mo concentrations at one of our study sites (up to $130 \mathrm{ppm}$ ). Through their activity, cable bacteria may modulate Mo records in our lake sediments by oxidising the surface sediment and mobilising both $\mathrm{Mn}$ and Mo, but further research is needed to quantify these effects and assess whether this plays a role in other marine systems. Oxygen measurements reveal an improvement in bottom water oxygen conditions, related to increased flushing of the lake with North Sea water since the late 1990s. This contrasts with the sediment Mo record for the deepest site, which suggests periods of increased pore water sulphide concentrations between 1999 and 
2012. These conflicting results are attributed to the input of fresh algal material ( $P$ globosa $)$ in late spring and summer with the North Sea water, which likely fuelled additional sulphate reduction and sulphide production in the pore water and enhanced Mn refluxing and hence the supply of Mo to the sediment. Since the increased oxygen demand is outpaced by the increased oxygen supply associated with the flushing, the bottom-water oxygen conditions at the site have improved.

\section{Acknowledgements}

We thank P van Rijswijk, S Hidalgo, S van der Linde, C Lenz, the crew of the R/V Luctor (P Coomans and M Kristalijn) and various other members of the NIOZ and UU teams for their support during the sampling campaigns. We are also grateful to J Sinke, A Tramper, T Zalm and D van de Meent for analytical support, O Stiekema and L Bik for assistance with sample preparation and $\mathrm{H}$ de Waard for assistance with (LA-)ICP-MS analyses. This research was financially supported by the Darwin Centre for Biogeosciences, the European Research Council, under the European Community's Seventh Framework Programme (ERC Starting Grants 278364 to CPS and 306933 to FJRM), the Netherlands Organisation for Scientific Research (NWO Vici 865.13.005 to CPS) and the National Ocean and Coastal Research Programme (grant 83910502).

\section{References}

Adelson, J.M., Helz, G.R., Miller, C.V., 2001a. Reconstructing the rise of recent coastal anoxia; molybdenum in Chesapeake Bay sediments. Geochimica Et Cosmochimica Acta, 65(2): 237252.

Adelson, J.M., Helz, G.R., Miller, C.V., 2001b. Reconstructing the rise of recent coastal anoxia; molybdenum in Chesapeake Bay sediments1. Geochimica et Cosmochimica Acta, 65(2): 237252.

Algeo, T.J., Lyons, T.W., 2006. Mo-total organic carbon covariation in modern anoxic marine environments: Implications for analysis of paleoredox and paleohydrographic conditions. Paleoceanography, 21(1): PA1016. 
Algeo, T.J., Tribovillard, N., 2009. Environmental analysis of paleoceanographic systems based on molybdenum-uranium covariation. Chemical Geology, 268(3-4): 211-225.

Boudreau, B.P., 1997. Diagenetic Models and their Implementation. Springer, 414p pp.

Carstensen, J. et al., 2014. Hypoxia in the Baltic Sea: Biogeochemical Cycles, Benthic Fauna, and Management. AMBIO, 43(1): 26-36.

Chappaz, A. et al., 2014. Does pyrite act as an important host for molybdenum in modern and ancient euxinic sediments? Geochimica et Cosmochimica Acta, 126: 112-122.

Cline, J.D., 1969. Spectrophotometric determination of hydrogen sulfide in natural waters. Limnology and Oceanography, 14(3): 454-458.

Collier, R.W., 1985. Molybdenum in the Northeast Pacific Ocean1. Limnology and Oceanography, 30(6): 1351-1354.

Crusius, J., Calvert, S., Pedersen, T., Sage, D., 1996. Rhenium and molybdenum enrichments in sediments as indicators of oxic, suboxic and sulfidic conditions of deposition. Earth and Planetary Science Letters, 145(1): 65-78.

Dahl, T.W. et al., 2017. Evidence of molybdenum association with particulate organic matter under sulfidic conditions. Geobiology, 15(2): 311-323.

Diaz, R.J., Rosenberg, R., 2008. Spreading Dead Zones and Consequences for Marine Ecosystems. Science, 321(5891): 926-929.

Egger, M. et al., 2016. Rapid Sediment Accumulation Results in High Methane Effluxes from Coastal Sediments. PLOS ONE, 11(8): e0161609.

Emerson, S.R., Huested, S.S., 1991. Ocean anoxia and the concentrations of molybdenum and vanadium in seawater. Marine Chemistry, 34(3): 177-196.

Erickson, B.E., Helz, G.R., 2000. Molybdenum(VI) speciation in sulfidic waters:: Stability and lability of thiomolybdates. Geochimica et Cosmochimica Acta, 64(7): 1149-1158.

Freund, C. et al., 2016. The effect of a thiol-containing organic molecule on molybdenum adsorption onto pyrite. Geochimica et Cosmochimica Acta, 174: 222-235.

Goldberg, T. et al., 2012. Controls on Mo isotope fractionations in a Mn-rich anoxic marine sediment, Gullmar Fjord, Sweden. Chemical Geology, 296-297: 73-82.

Gooday, A.J. et al., 2009. Historical records of coastal eutrophication-induced hypoxia. Biogeosciences, 6(8): 1707-1745.

Hagens, M. et al., 2015. Biogeochemical processes and buffering capacity concurrently affect acidification in a seasonally hypoxic coastal marine basin. Biogeosciences, 12(5): 1561-1583.

Helz, G.R., Adelson, J.M., 2013. Trace element profiles in sediments as proxies of dead zone history; rhenium compared to molybdenum. Environ Sci Technol, 47(3): 1257-64.

Helz, G.R. et al., 1996. Mechanism of molybdenum removal from the sea and its concentration in black shales: EXAFS evidence. Geochimica et Cosmochimica acta, 60(19): 3631-3642.

Hennekam, R., Jilbert, T., Mason, P.R.D., de Lange, G.J., Reichart, G.-J., 2015. High-resolution line-scan analysis of resin-embedded sediments using laser ablation-inductively coupled plasma-mass spectrometry (LA-ICP-MS). Chemical Geology, 403: 42-51.

Jilbert, T., De Lange, G.J., Reichart, G.-J., 2008. Fluid displacive resin embedding of laminated sediments: preserving trace metals for high-resolution paleoclimate investigations. Limnology and Oceanography: Methods, 6: 16-22.

Jilbert, T., Slomp, C.P., 2013a. Iron and manganese shuttles control the formation of authigenic phosphorus minerals in the euxinic basins of the Baltic Sea. Geochimica et Cosmochimica acta, 107(0): 155-169.

Jilbert, T., Slomp, C.P., 2013b. Rapid high-amplitude variability in Baltic Sea hypoxia during the Holocene. Geology, 41(11): 1183-1186.

Levin, L.A. et al., 2009. Effects of natural and human-induced hypoxia on coastal benthos. Biogeosciences, 6(10): 2063-2098.

Li, Y.-H., Gregory, S., 1974. Diffusion of ions in sea water and in deep-sea sediments. Geochimica et Cosmochimica Acta, 38(5): 703-714. 
Madison, A.S., Tebo, B.M., Mucci, A., Sundby, B., Luther, G.W., 2013. Abundant Porewater Mn(III) Is a Major Component of the Sedimentary Redox System. Science, 341(6148): 875-878.

Malcolm, S.J., 1985. Early diagenesis of molybdenum in estuarine sediments. Marine Chemistry, 16(3): 213-225.

Malkin, S.Y. et al., 2014. Natural occurrence of microbial sulphur oxidation by long-range electron transport in the seafloor. ISME J.

Miller, C.A., Peucker-Ehrenbrink, B., Walker, B.D., Marcantonio, F., 2011. Re-assessing the surface cycling of molybdenum and rhenium. Geochimica et Cosmochimica Acta, 75(22): 7146-7179.

Millero, F.J., Plese, T., Fernandez, M., 1988. The dissociation of hydrogen sulfide in seawater1. Limnology and Oceanography, 33(2): 269-274.

Morford, J.L. et al., 2007. Insights on geochemical cycling of $U$, Re and Mo from seasonal sampling in Boston Harbor, Massachusetts, USA. Geochimica et Cosmochimica acta, 71(4): 895-917.

Mort, H., Slomp, C., Gustafsson, B.G., Andersen, T.J., 2010. Phosphorus recycling and burial in Baltic Sea sediments with contrasting redox conditions. Geochimica \& Cosmochimica acta, 74: 13501362.

Nielsen, L.P., Risgaard-Petersen, N., Fossing, H., Christensen, P.B., Sayama, M., 2010. Electric currents couple spatially separated biogeochemical processes in marine sediment. Nature, 463(7284): 1071-1074.

Olson, L. et al., 2017. Trace metal diagenesis in sulfidic sediments: Insights from Chesapeake Bay. Chemical Geology, 452: 47-59.

Paulij, W.P., Bogaards, R.H., Denucé, J.M., 1990. Influence of salinity on embryonic development and the distribution of Sepia officinalis in the Delta Area (South Western part of The Netherlands). Marine Biology, 107(1): 17-23.

Pfeffer, C. et al., 2012. Filamentous bacteria transport electrons over centimetre distances. Nature, 491(7423): 218-221.

Rabalais, N.N. et al., 2014. Eutrophication-Driven Deoxygenation in the Coastal Ocean Oceanography, 27.

Rabalais, N.N. et al., 2010. Dynamics and distribution of natural and human-caused hypoxia. Biogeosciences, 7(2): 585-619.

Rao, A.M.F., Malkin, S.Y., Hidalgo-Martinez, S., Meysman, F.J.R., 2016. The impact of electrogenic sulfide oxidation on elemental cycling and solute fluxes in coastal sediment. Geochimica et Cosmochimica Acta, 172: 265-286.

Risgaard-Petersen, N., Revil, A., Meister, P., Nielsen, L.P., 2012. Sulfur, iron-, and calcium cycling associated with natural electric currents running through marine sediment. Geochimica et Cosmochimica acta, 92(0): 1-13.

Roepert, A., Jilbert, T., Slomp, C.P., 2016. Calibration of LA-ICP-MS line scan data to obtain highresolution geochemical records of resin-embedded sediment cores. Geochemistry, Geophysics, Geosystems. Technical Reports: Methods: (submitted).

Scheiderich, K., Helz, G.R., Walker, R.J., 2010. Century-long record of Mo isotopic composition in sediments of a seasonally anoxic estuary (Chesapeake Bay). Earth and Planetary Science Letters, 289(1-2): 189-197.

Scholz, F., McManus, J., Sommer, S., 2013. The manganese and iron shuttle in a modern euxinic basin and implications for molybdenum cycling at euxinic ocean margins. Chemical Geology, 355(0): 56-68.

Scott, C., Lyons, T.W., 2012. Contrasting molybdenum cycling and isotopic properties in euxinic versus non-euxinic sediments and sedimentary rocks: Refining the paleoproxies. Chemical Geology, 324-325: 19-27.

Seitaj, D. et al., 2015. Cable bacteria generate a firewall against euxinia in seasonally hypoxic basins. Proceedings of the National Academy of Sciences, 112(43): 13278-13283.

Seitaj, D. et al., 2016. Sedimentary oxygen dynamics in a seasonally hypoxic basin. Limnology and Oceanography. 
Shimmield, G.B., Price, N.B., 1986. The behaviour of molybdenum and manganese during early sediment diagenesis - offshore Baja California, Mexico. Marine Chemistry, 19(3): 261-280.

Soetaert, K., Petzoldt, T., Meysman, F., 2010. Marelac: Tools for aquatic sciences. R package version.

Sulu-Gambari, F. et al., 2016b. Impact of Cable Bacteria on Sedimentary Iron and Manganese Dynamics in a Seasonally-Hypoxic Basin. Geochimica et Cosmochimica Acta.

Sulu-Gambari, F. et al., 2016a. Cable Bacteria Control Iron-Phosphorus Dynamics in Sediments of a Coastal Hypoxic Basin. Environmental Science \& Technology, 50(3): 1227-1233.

Tribovillard, N., Algeo, T.J., Lyons, T., Riboulleau, A., 2006. Trace metals as paleoredox and paleoproductivity proxies: An update. Chemical Geology, 232(1-2): 12-32.

Turekian, K.K., Wedepohl, K.H., 1961. Distribution of the Elements in Some Major Units of the Earth's Crust. Geological Society of America Bulletin, 72(2): 175-192.

Wagner, M., Chappaz, A., Lyons, T.W., 2017. Molybdenum speciation and burial pathway in weakly sulfidic environments: Insights from XAFS. Geochimica et Cosmochimica Acta, 206: 18-29.

Wedepohl, K.H., 1991. Chemical composition and fractionation of the continental crust. Geologische Rundschau, 80(2): 207-223.

Wetsteyn, L.P.M.J., 2011. Grevenlingenmeer: meer kwetsbaar?, RWS Waterdienst, Lelystad.

Zheng, Y., Anderson, R.F., van Geen, A., Kuwabara, J., 2000. Authigenic molybdenum formation in marine sediments: a link to pore water sulfide in the Santa Barbara Basin. Geochimica et Cosmochimica Acta, 64(24): 4165-4178.

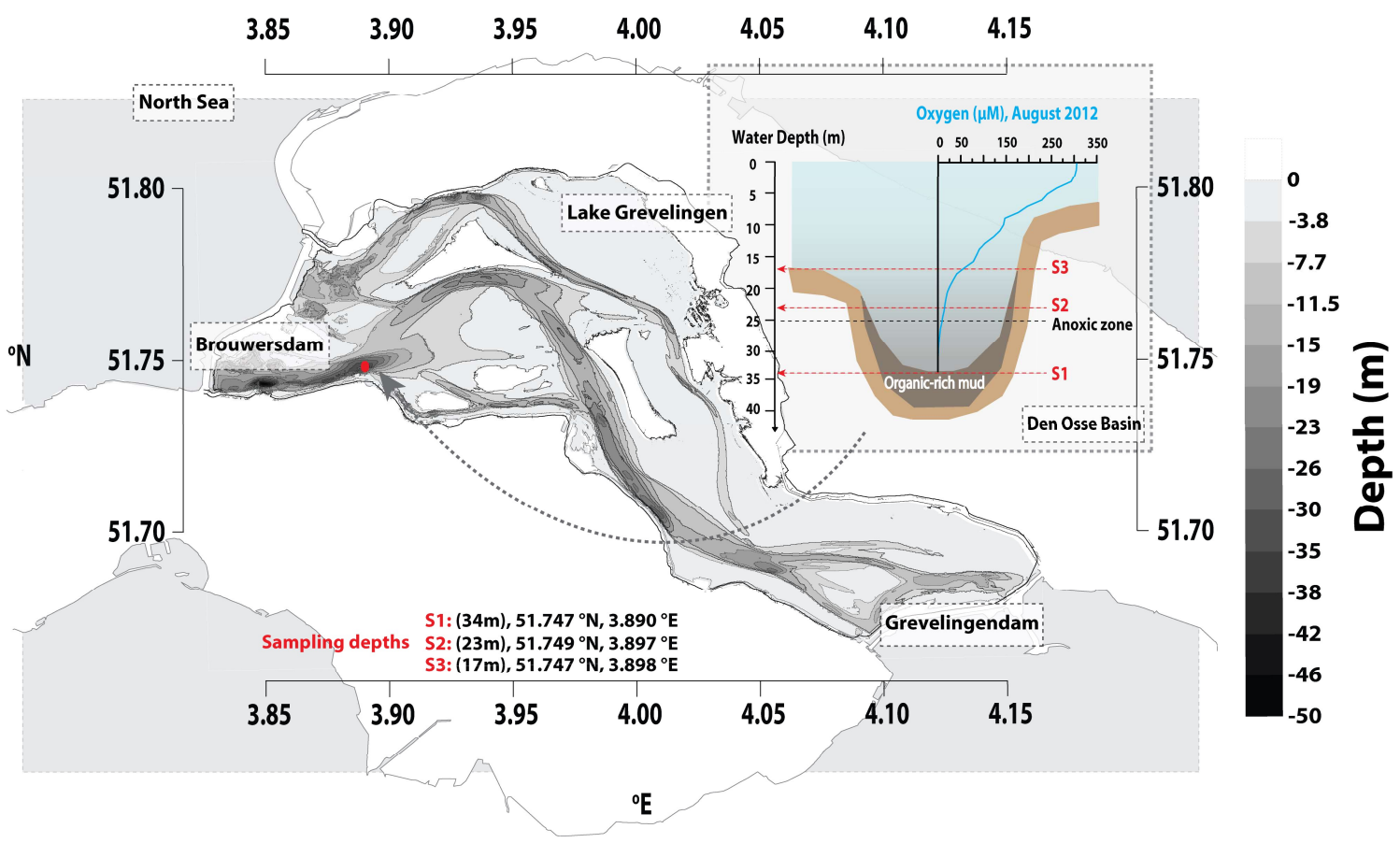

Figure 1: Location of the Den Osse basin at the south-western edge of Lake Grevelingen. Sediment samples

were collected from three sites (S1-S3) along a water depth gradient from January to December 2012 (inset). The water column oxygen concentration as a function of water depth for site 1 is plotted for the most anoxic period of the sampling year, August 2012. 

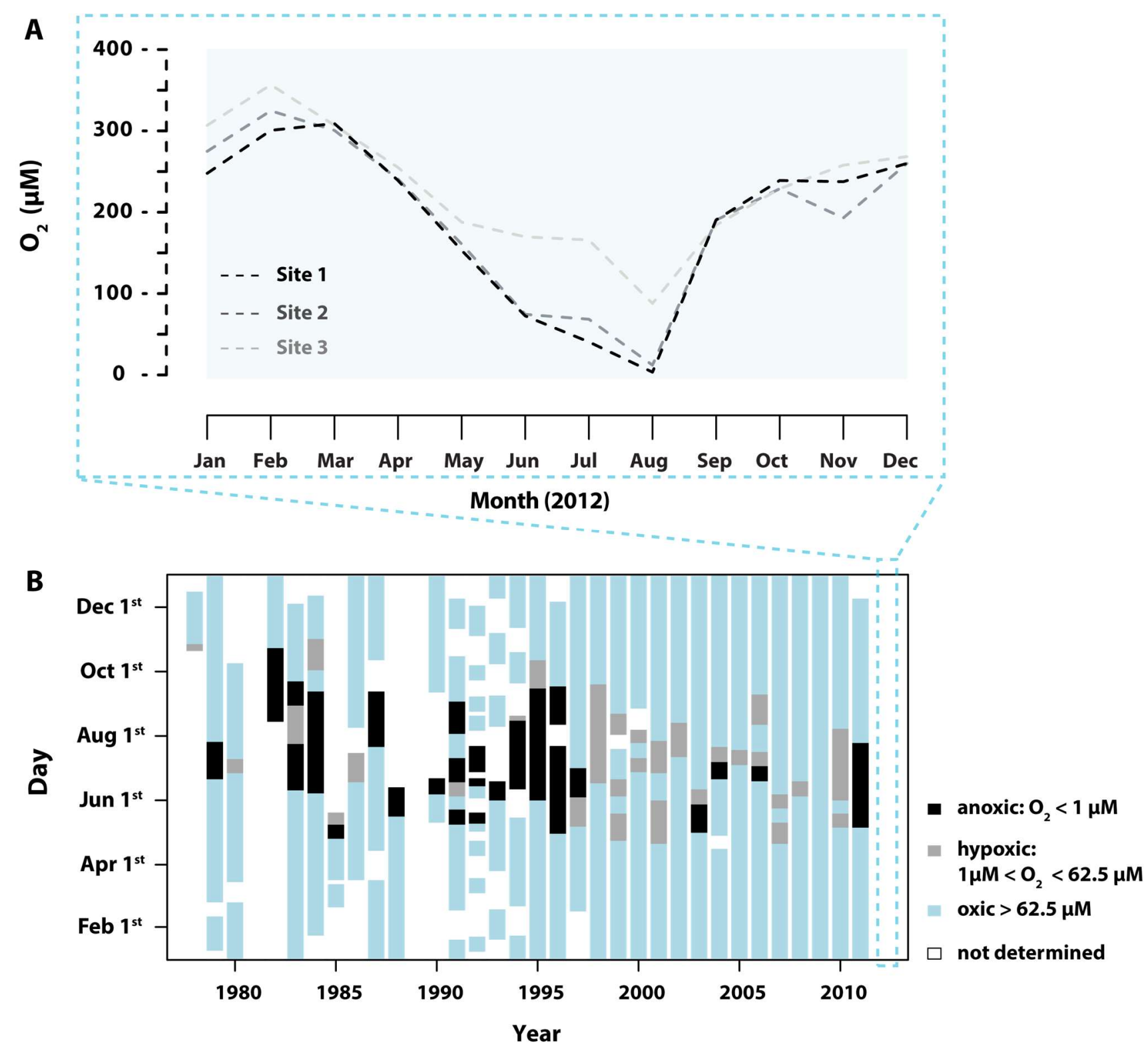

729 Figure 2: (A) Monthly bottom-water oxygen concentrations (in $\mu \mathrm{M}$ ) at all three sites from January to December 730 2012. (B) Periods of oxic, hypoxic and anoxic bottom water conditions from 1999 to 2011 at site 1 (Ministry of 731 Infrastructure and Environment (Wetsteyn, 2011)). 


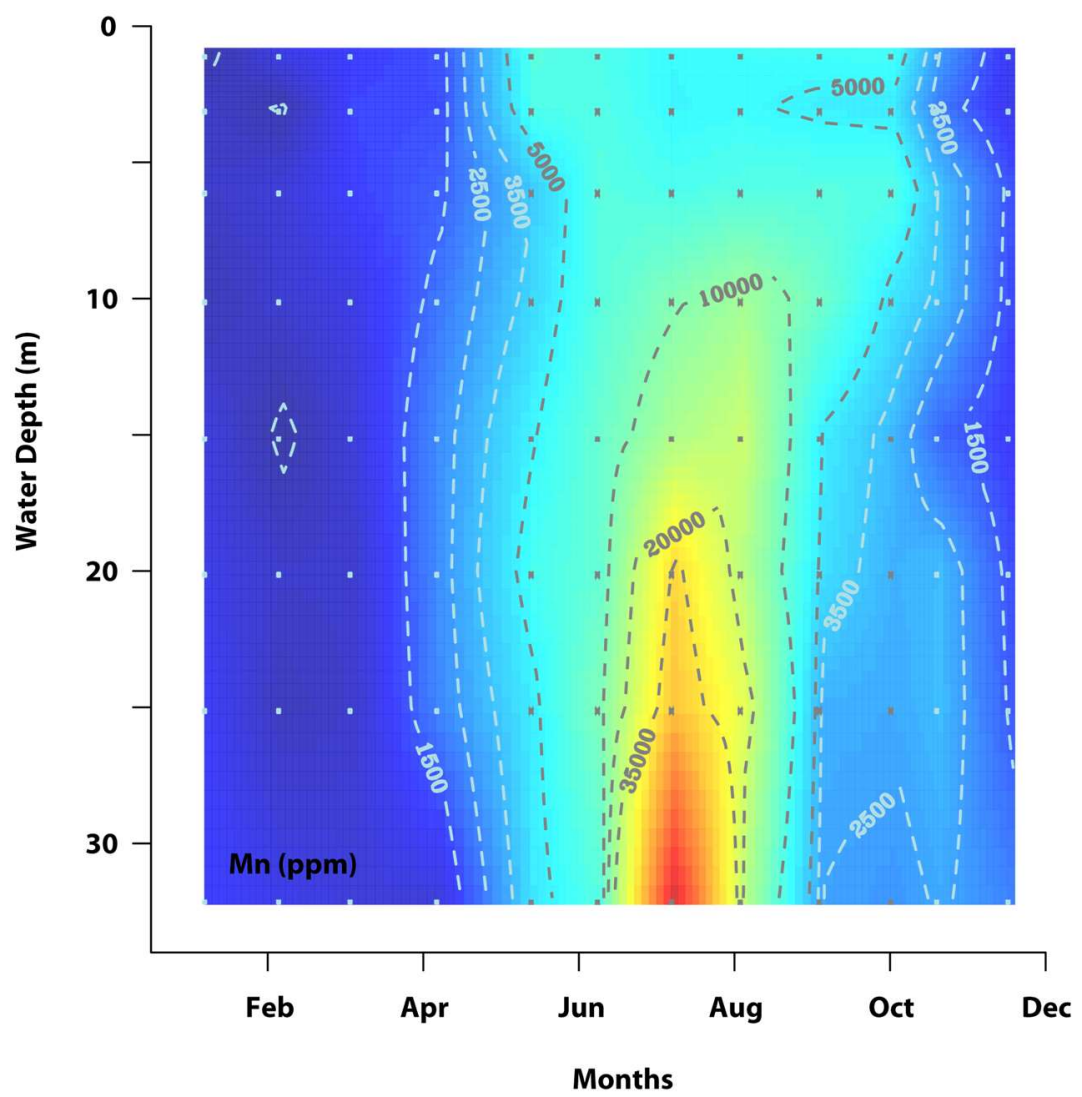

735 Figure 3: Concentrations of total $\mathrm{Mn}$ in suspended matter (in ppm) at site 1 for 2012. Note that a similar pattern

736 with depth and time is observed when Mn concentrations are expressed per volume of water; Figure S2). Data 737 are provided in Table S2. 


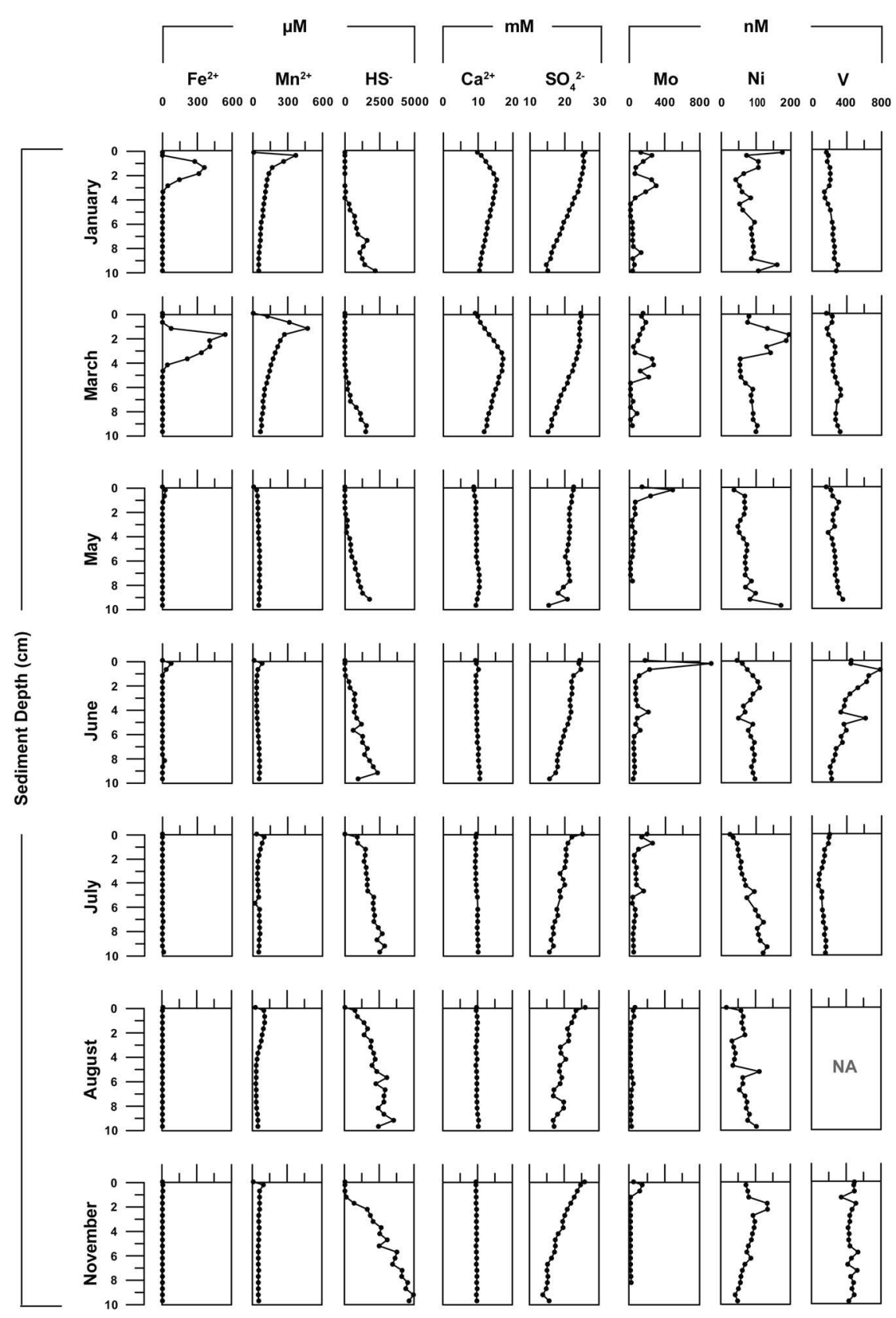

739 Figure 4: Pore water profiles of $\mathrm{Fe}^{2+}, \mathrm{Mn}^{2+}, \mathrm{HS}^{-}, \mathrm{Ca}^{2+}, \mathrm{SO}_{4}^{2-}$, Mo, Ni and $\mathrm{V}$ for January, March, May, June, July, August and November 2012 at site 1. Data are provided in Table S3. 


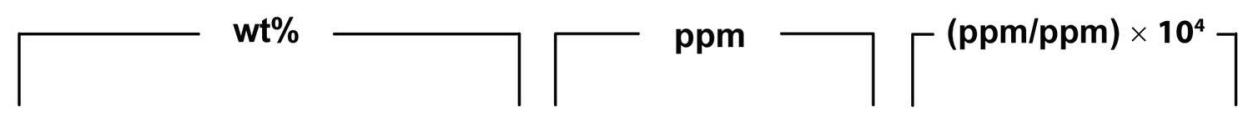

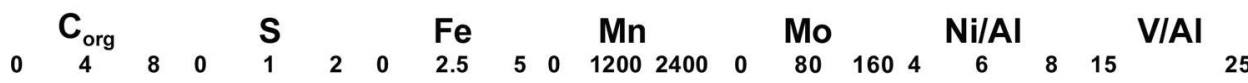
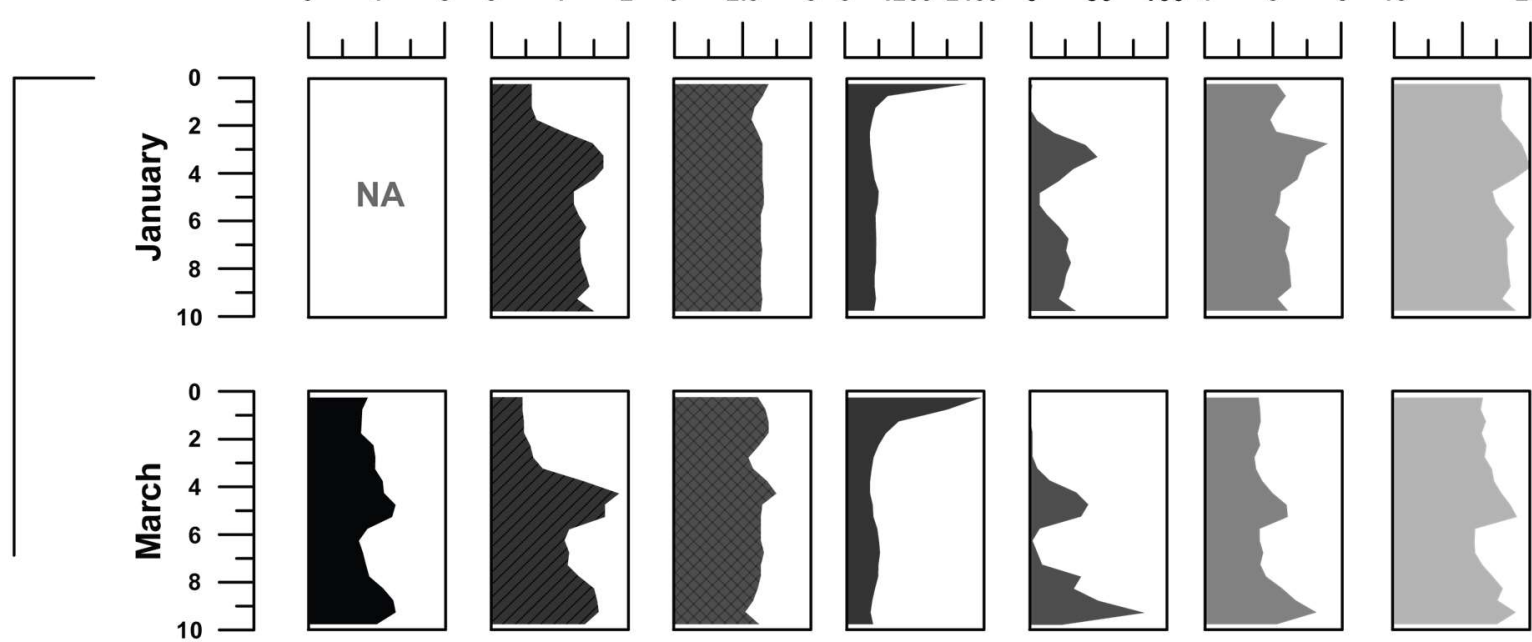

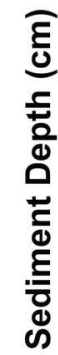
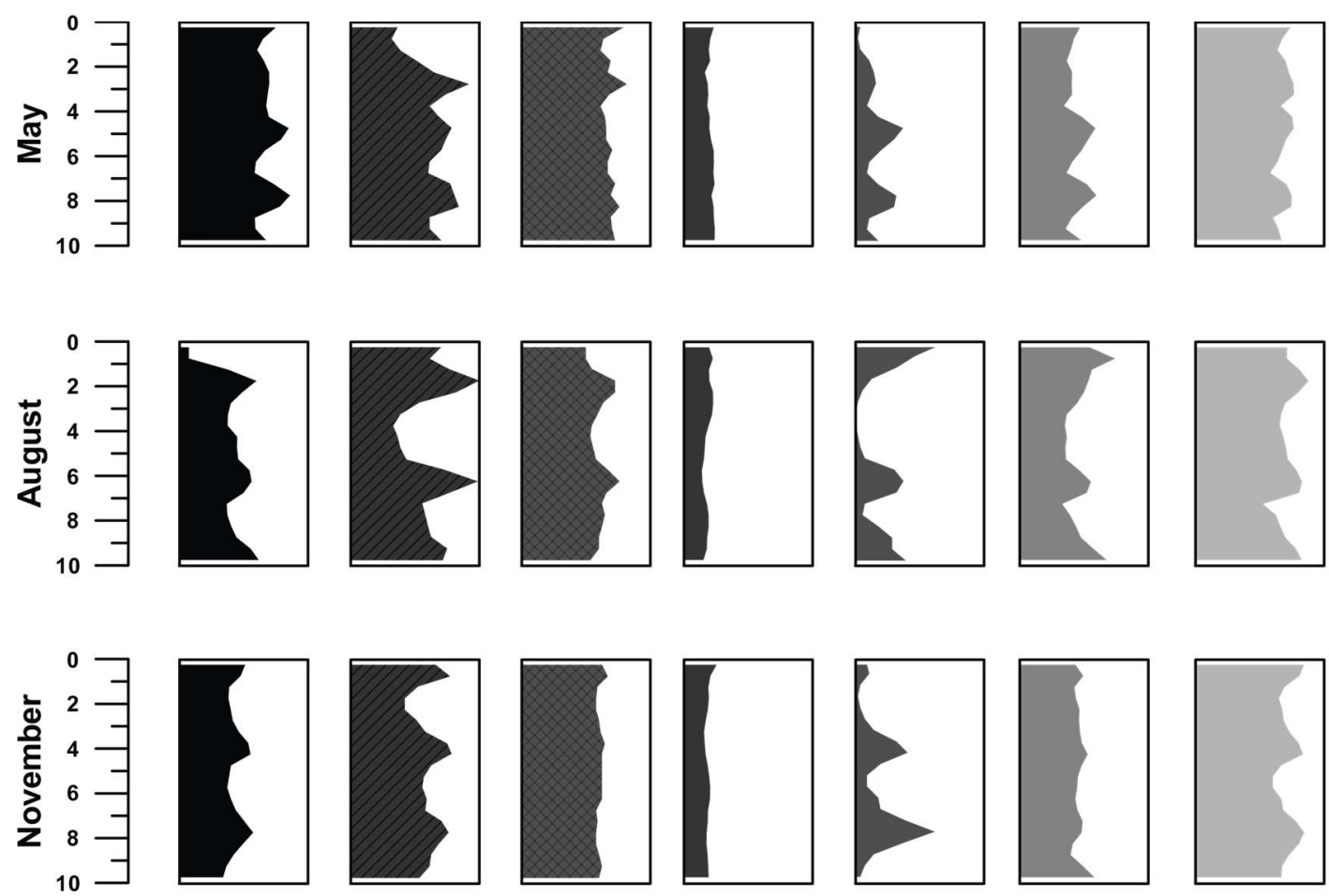

Figure 5: Sediment profiles of $\mathrm{C}_{\mathrm{org}}$, total $\mathrm{S}, \mathrm{Fe}, \mathrm{Mn}, \mathrm{Mo}, \mathrm{Ni} / \mathrm{Al}$ and $\mathrm{V} / \mathrm{Al}$ for January, March, May, August and

November 2012 at site 1 . Nickel and vanadium are normalised to aluminium to account for the high background in Table S4. 


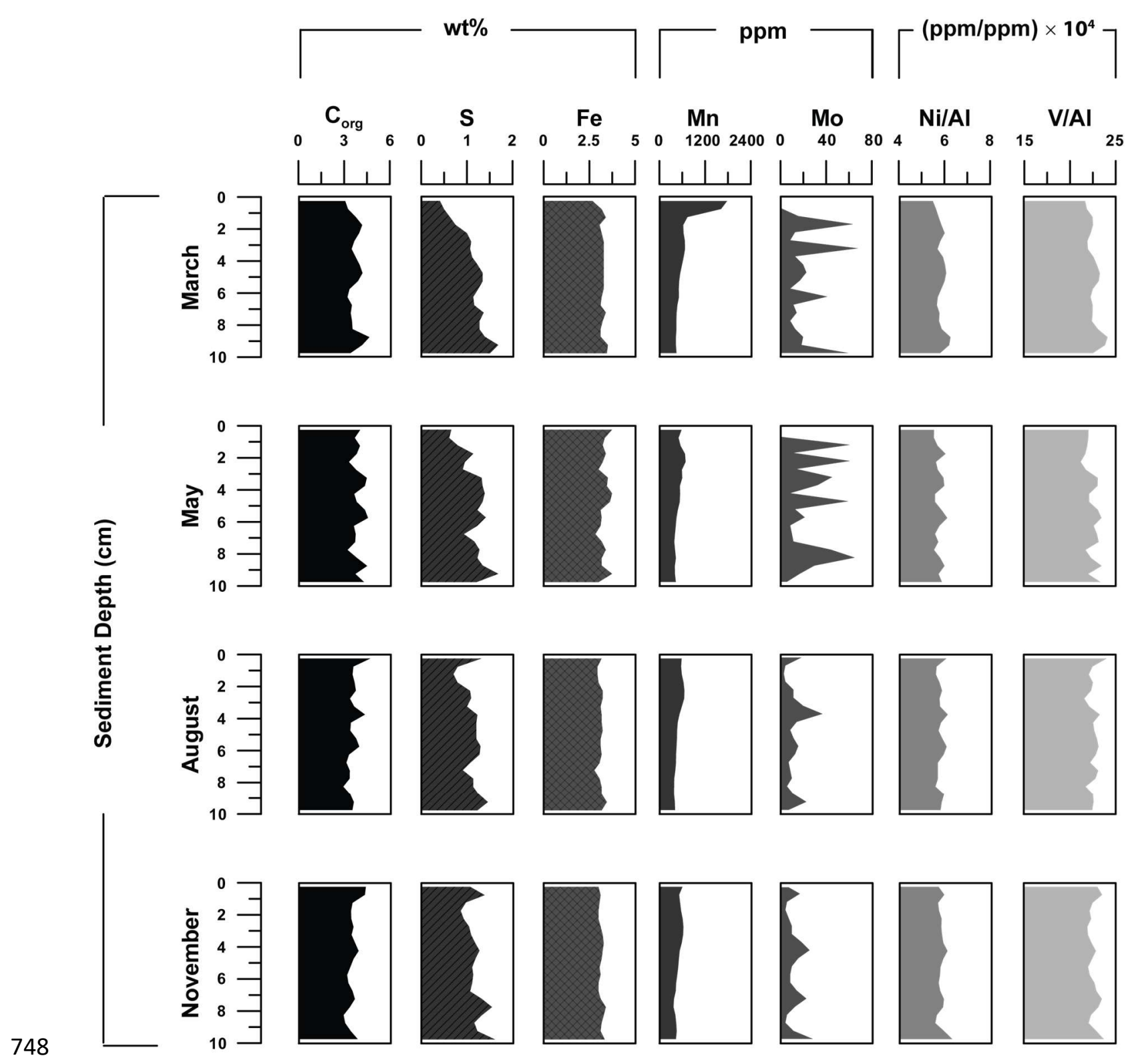

749 Figure 6: Sediment profiles of $\mathrm{C}_{\text {org }}$, total $\mathrm{S}, \mathrm{Fe}, \mathrm{Mn}, \mathrm{Mo}, \mathrm{Ni} / \mathrm{Al}$ and $\mathrm{V} / \mathrm{Al}$ for March, May, August and November 7502012 at site 2. Note that site 2 was not sampled in January 2012. Data are provided in Table S4. 


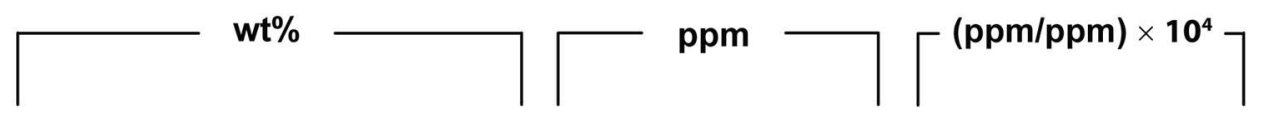

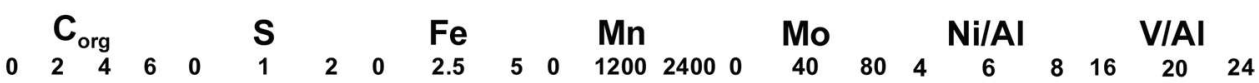
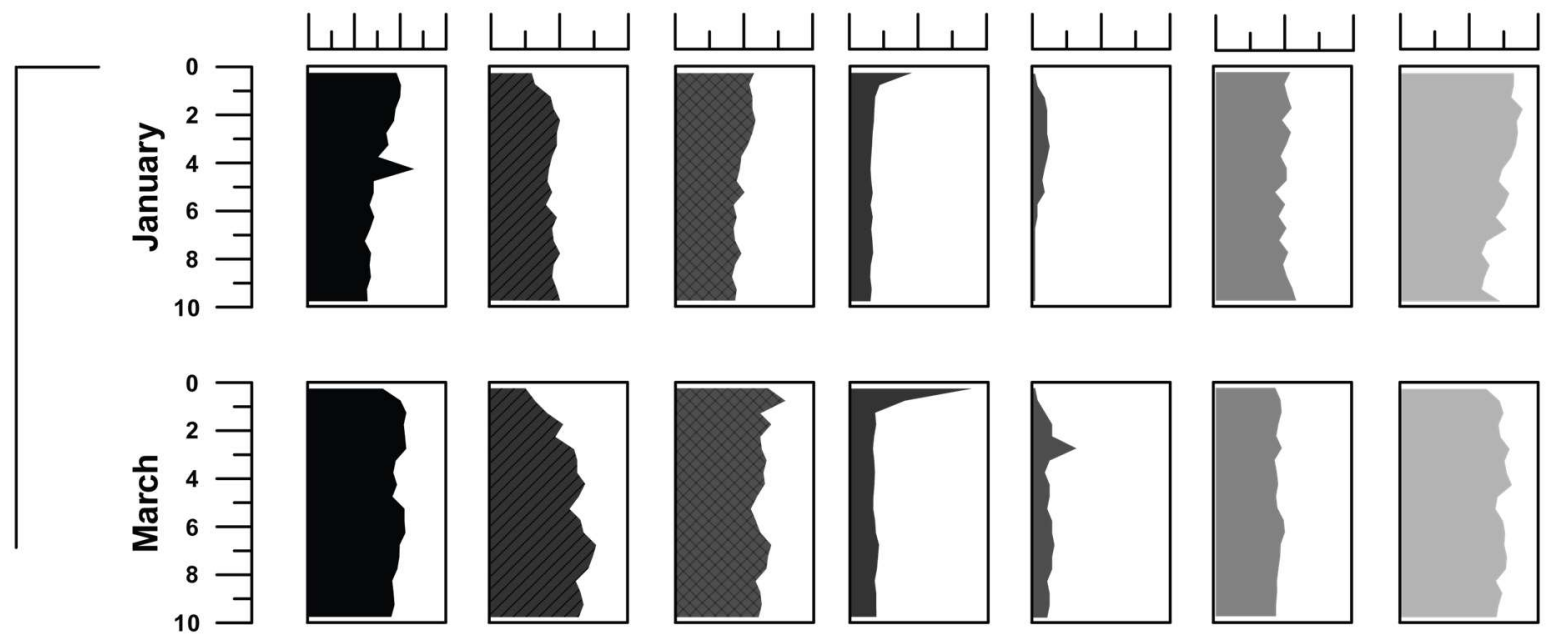

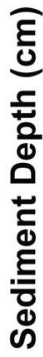
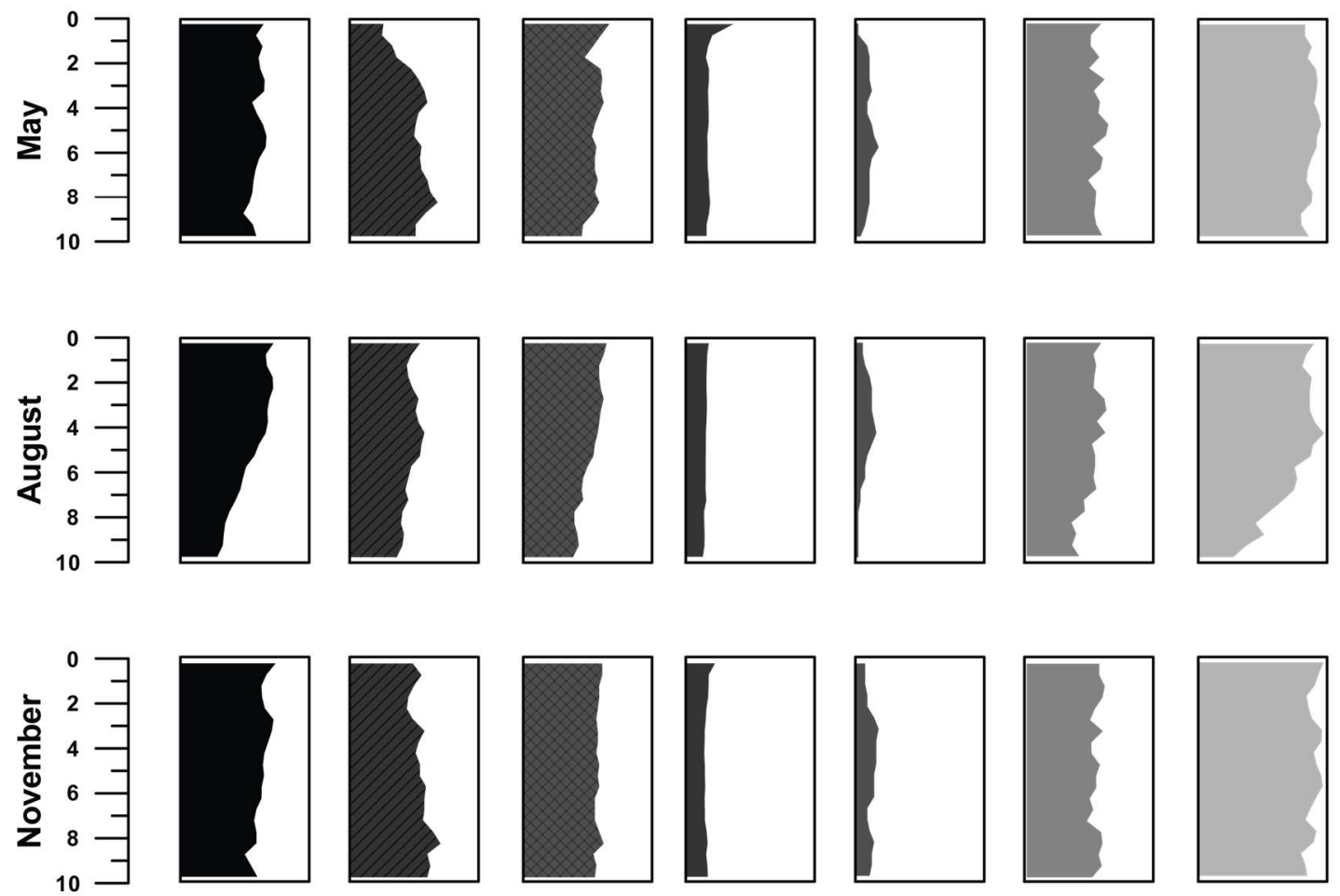

Figure 7: Sediment profiles of $\mathrm{C}_{\text {org }}$, total $\mathrm{S}, \mathrm{Fe}, \mathrm{Mn}, \mathrm{Mo}, \mathrm{Ni} / \mathrm{Al}$ and $\mathrm{V} / \mathrm{Al}$ for March, May, August and November 2012 at site 3 . Data are provided in Table S4. 


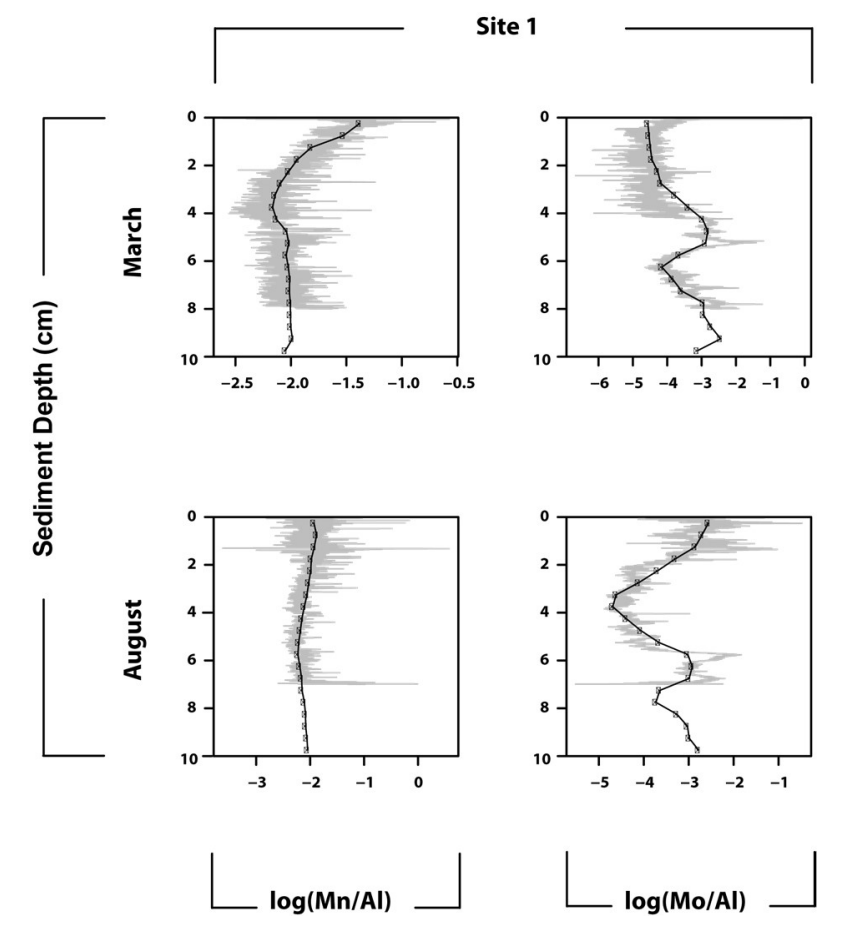

758 Figure 8: Sediment profiles of $\log (\mathrm{Mn} / \mathrm{Al})$ and $\log (\mathrm{Mo} / \mathrm{Al})$ for March and August 2012 at site 1 as obtained with 759 LA-ICP-MS (grey lines) and discrete sampling followed by total elemental analysis (black lines and dots). Data 760 are provided in Tables S6 and 7.

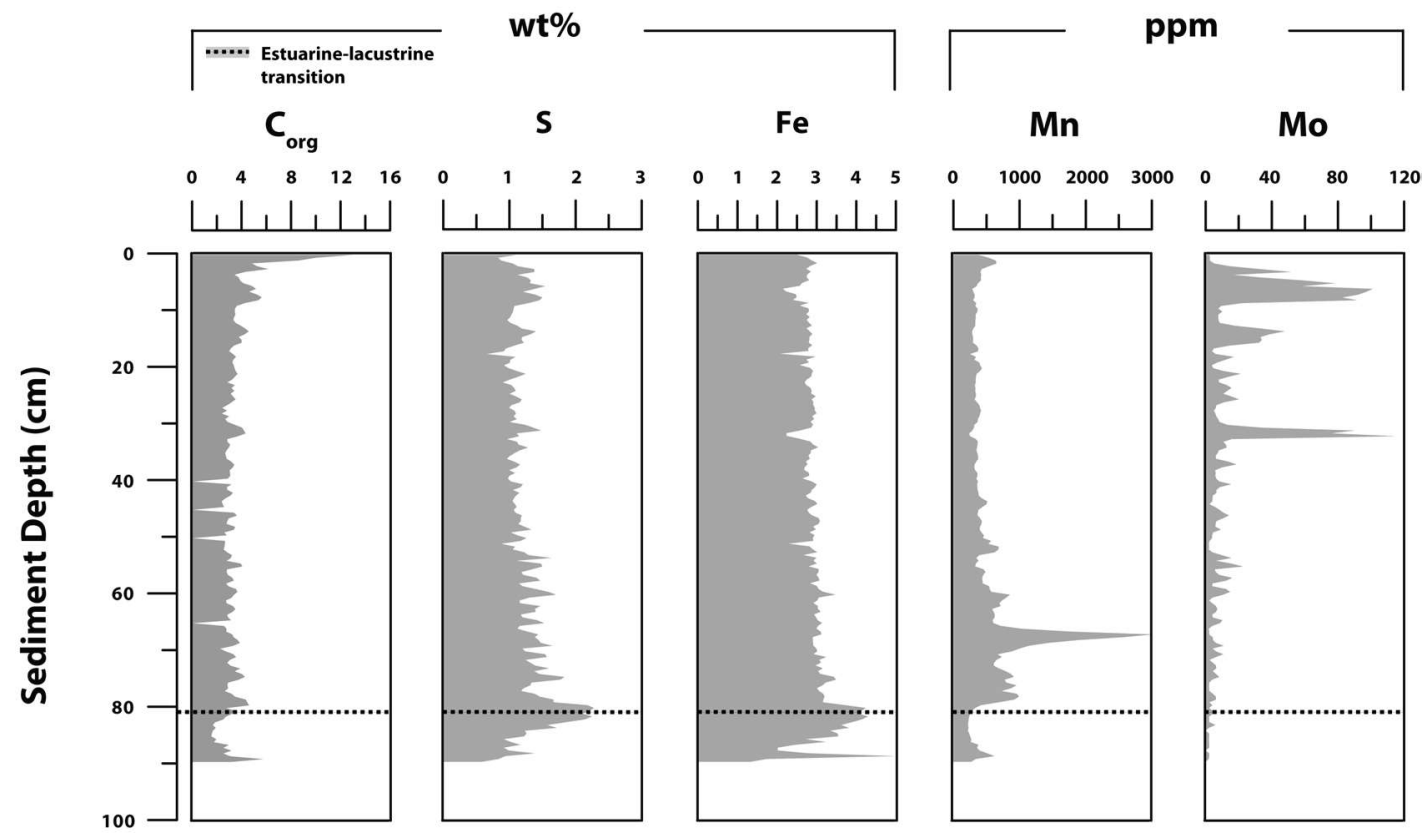

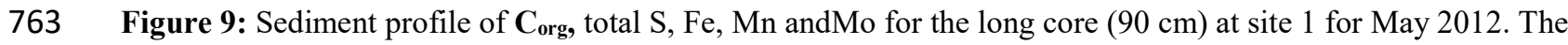
estuarine-lacustrine transition is indicated with a dotted line. Data are provided in Table S5. 
Table 1: Calculated diffusive molybdenum fluxes at the sediment-water interface (SWI) and deeper in the sediment. *Calculated in R, with an adapted version of the marelac package (see section 2.6), using bottom water salinity and temperature measurements from (Hagens et al., 2015). Positive fluxes are directed upwards, out of the sediment.

\begin{tabular}{ccccc}
\hline Diffusive Fluxes Mo & \multicolumn{5}{c}{ SWI (0-0.25 $\mathrm{cm})$} & Deeper flux & \\
\hline Site 1 & Diffusion Coefficient* $\left(\mathrm{cm}^{2} \mathbf{s}^{-1}\right)$ & $\mathrm{mg} \mathrm{m}^{-2} \mathrm{~d}^{-1}$ & Corresponding Depth Interval $(\mathbf{c m})$ & $\mathrm{mg} \mathrm{m}^{-2} \mathbf{d}^{-1}$ \\
\hline Jan & $5.45 \mathrm{E}-06$ & 0.19 & $3.75-4.25$ & -0.04 \\
Mar & $5.27 \mathrm{E}-06$ & -0.03 & $5.25-5.75$ & -0.15 \\
May & $6.07 \mathrm{E}-06$ & 0.60 & $0.75-1.25$ & -0.14 \\
Jun & $6.21 \mathrm{E}-06$ & 1.39 & $0.75-1.25$ & -0.11 \\
Jul & $7.12 \mathrm{E}-06$ & -0.13 & $1.25-1.75$ & -0.05 \\
Aug & $7.47 \mathrm{E}-06$ & -0.04 & $0.75-1.25$ & -0.04 \\
Nov & $6.62 \mathrm{E}-06$ & 0.18 & $0.75-1.25$ & -0.10 \\
\hline
\end{tabular}

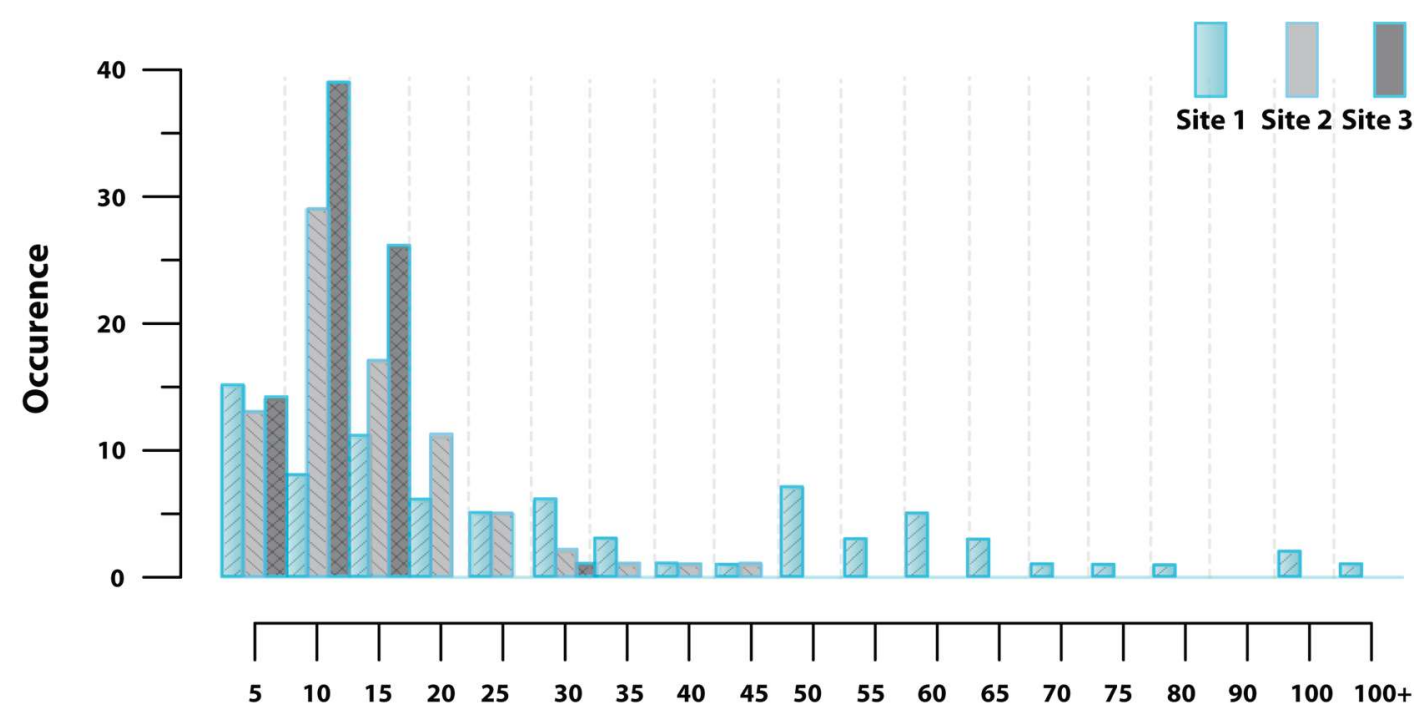

772 Figure 10: Number of samples with Mo concentrations (ppm) in different concentration ranges at sites 1-3 (after

773 (Scott and Lyons, 2012)). Where sulphide is present but restricted to the pore waters, sediment Mo concentrations 774 do not typically exceed $25 \mathrm{ppm}$. Conversely, in euxinic environments where hydrogen sulphide is present in the water column throughout the year, and dissolved Mo is abundant due to effective exchange with the open ocean, enrichments display a much wider range with concentrations consistently $>100$ ppm (Scott and Lyons, 2012). 


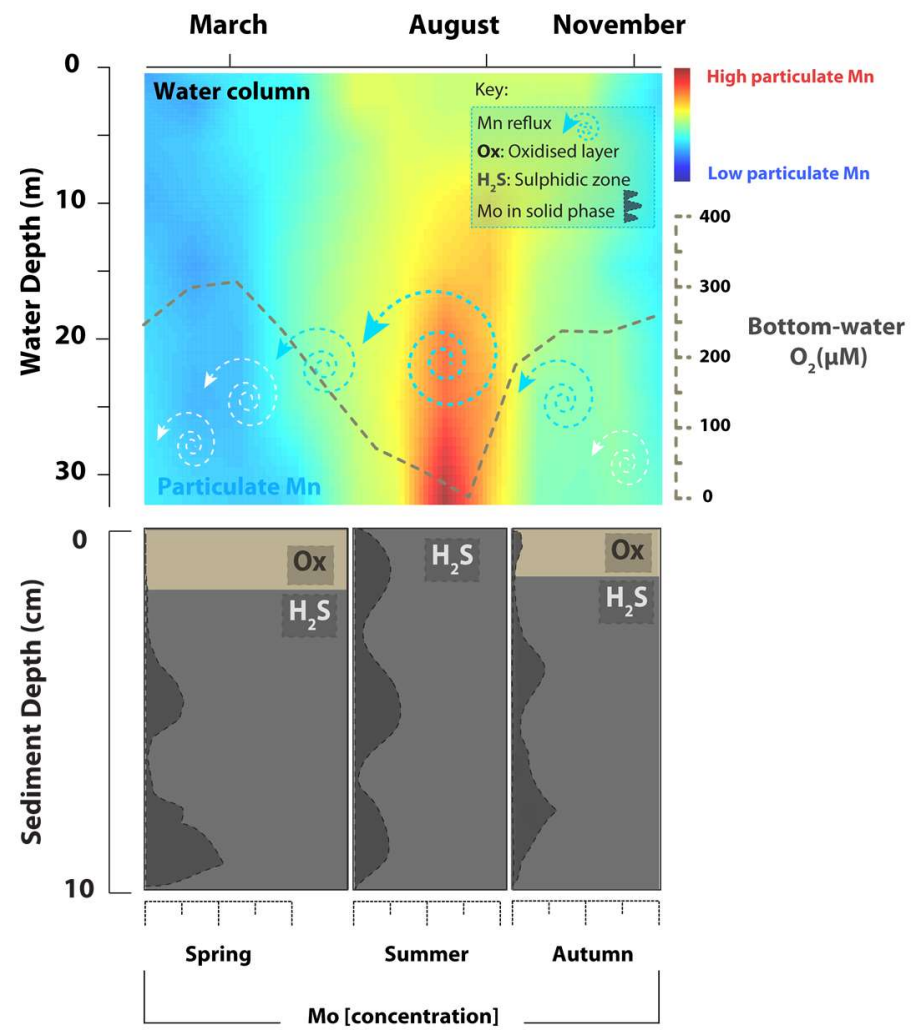

779 Figure 11: Schematic of Mo and Mn dynamics in the sediment and water column at site 1 in spring, summer and

780 late autumn. Upper panel: particulate $\mathrm{Mn}$ in the water column. Lower panel: schematic representation of sediment 781 Mo profiles. 